\title{
ACKNOWLEDG EJUENTS
}

To Ben and Paul, for finding the time and going the distance. To Duncan, for valuable assistance and encouragement.

Bush

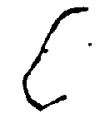

Ottawa, Canada

2 September, 1984. 
National Library

of Canada

Canadian Theses Service

Ottawa, Canada

K1A ONA
Bibliotheque natıonale

dı Canada

Services des thèses canadiennes
CANADIAN THESES

\section{NOTICE}

The quality of this microfiche is heavily dependent upon the quality of the original thessis submitted for microfilmıng. Every effort has been made to ensure the highest quality of reproduction possible,

If pages are missing, contact the university which granted the degrèe.

Some pages may have indistinct print especially if the orignal pages were typed with a poor typewriter ribbon or if the university sent us an inferior photocopy.

Pieviously copyrighted materials (journal articles, published tests, etc ) are not filmed.

Reproduch in full or in part of this film is governed by the Canadian Copyright Act, R.S.C. 1970, C. C-30. Please read the authorization forms which accompany this thesis

\section{THIS DISSERTATION HAS BEEN MICROFILMED EXACTLY AS RECEIVED.}

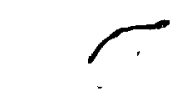

THĖSES CANADIÉNNES

AVIS

La qualité de cette microliche dépeno grandement de la qualiti" de la thèse soumıse au mıcrofilmage Nous avons tout fait pou: assurer une qualité supérieure de reproduction.

S'il manque des pages, veuillez communıquer avec l'unıversité qui a conféré le grade

La qualité d'impression de certames pages peut laisser à. désırer, surtout sı les pages orıgınales ont été dactylographiees à l'aıde d'un ruban usé ou si l'université nous a falt parvenır une photocopie de qualité ınférıeure

Les documents qui font déjà l'objet d'un droit d'auteur (articles de revue, examens publiés, etc) ne sont pas microfilmés

La reproduction, même partıelle, de ce microfılm est soumıse à la Loi canadienne sur le drolt d'auteur, SRC 1970, c. C-30 Veuillez prendre connaissance des formules d'autorisation qui accompagnent cette thèse

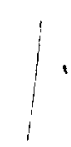

NL 339 (1 86/01) 
National Library

Bibliothèque nationale

of Canada

du Canada

$(y)$

Canadian Theses Division

Division des theses capadiennes

Ottawa, Canada

K1A ON4

\section{PERMISSION TO MICROFILM - AUTORISATION DEXICRIOFILMER}

- Please print or type - Écrire en lettres moulées ou dactylographier

Full Name of Author - Nom complet de l'auteur

Steven Arthur Bushey

Date of Birth - Date de naissance

02 December 1958

Country of Birth - Lieu de naissance

Vermont, U.S.A.

Permanent Address - Résidence fixe

$$
\begin{aligned}
& \text { 78. Lowis Street : } \\
& \text { Burlington. Vumont Os40i }
\end{aligned}
$$

,

Title of Thesis - Titre de la thèse

THE CATAMOUNT TRAIL: AN INTRODUCTION, PROPOSAI AND FEASIBILITY REVIEW

Universuty - Université

Carleton University

Degree for which thesis was presented - Grade pour lequel catte thèse fut présentèe;

M.A.

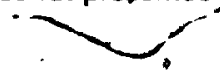

Year this degree conferred - Année diobtention de ce grade 1984

Name of Supervisor - Nom du directeur de thèse

D.M. Anderson

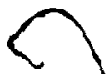

Permission is hereby granted to the NATIONAL LIBRARY OF CANADA to microfilm this thesis and to lend or sell copies of the film

The author reserves other publication rights, and neither the thesis hor extensive extracts from it may be printed or other. wise reproduced without the author's written permission.
Lautorisation est. par la présente, accordée à la BIBLIOTHE. QUE NATIONALE DÚ CANADA de microfilmer cette thèse et de prêter ou dévendre des exemplaires du film

L'auteur se réserve les autres droits de publication; ni la thèse ni de longs extraits de celle-ci ne doivent être imprimés ou autrement reproduits sans l'autorisation écrite de l'auteur.
Date

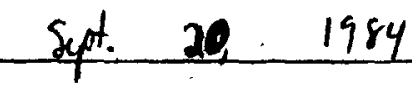

NL-91 (4/77).
Signature

$$
\text { Struevi }
$$

\section{A.} ' 
THE CATAMOUNT TRAIL: AN INTRODUCTION, ,

PROPCSAI AND FEASIEILITY REVIEN

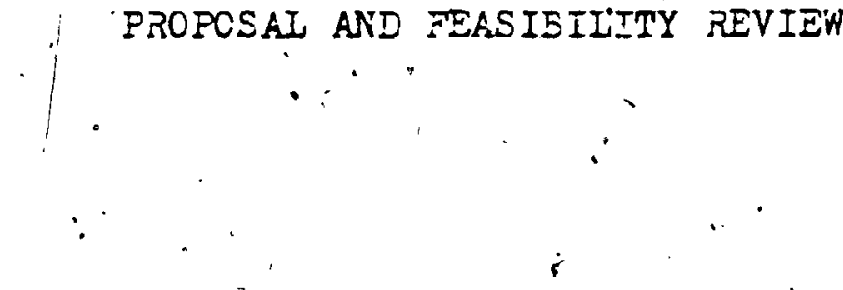

by

Steve Bushey, B.A. University of Vermont

Copyright $1984^{\prime}$ by Carleton University

A thesis submittec to the Faculty of Graduate Studies and Research in partial fulfillment of the requirements for the degree of Master of Ants

in Geography

es

.

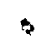

Department of Geography

Carleton University

Ottava, Ontário

(C) 7 septemoer, 1984 .

$4 x$ 
In the interests of facilitating research by others at this. institution and elsewhere, I hereby grant a licence to: '.

CARLETON UNIVERSITY

to make copies of mỳ thesis: -THE CATAMOUNT TRAIL: AN INTBQDUCIION, RROPOSAL AND FEASIBUIITY BEVIEW or substantial parts thereof the copyright which is invested in
me, provided. that the licerice is subject to the following conditions:

Only singled copies shall be made or authorized to be made at any one time, and only in response to a written request from the library of any university or similar institution on its own behalf or on behalf. of one of its users.

This' licence shall continue for the full term of the copyright, or for so long as may be legally permitted.

The Universal Copyright Notice shall appear on the title page of all copies made under the authority of this licence.

This licence does not permit the sale of authorized copies at. a profit, but does permit the collection by the institution or institutions concerned of charges covering actual costs.

All copies under the authority of this licence shall bear a statement to the effect that the copy in question "is being made available in this form by the authority of the copyright owner solely for the purpose of private study and research and. may not be copied or reproduced except as permitted by the copyright laws without writgen duthority from the copyright owner."

The foregoing shatl in no way preclude the granting by the author $\mathrm{O}_{\mathrm{f}}$ licence to the National Library of Canada to reproduce the thesis and to lend or to seli copies of the same. For this purpose it shall also be permissible for Carleton University to submit the abovementioned thesis to the National Library of Canada.
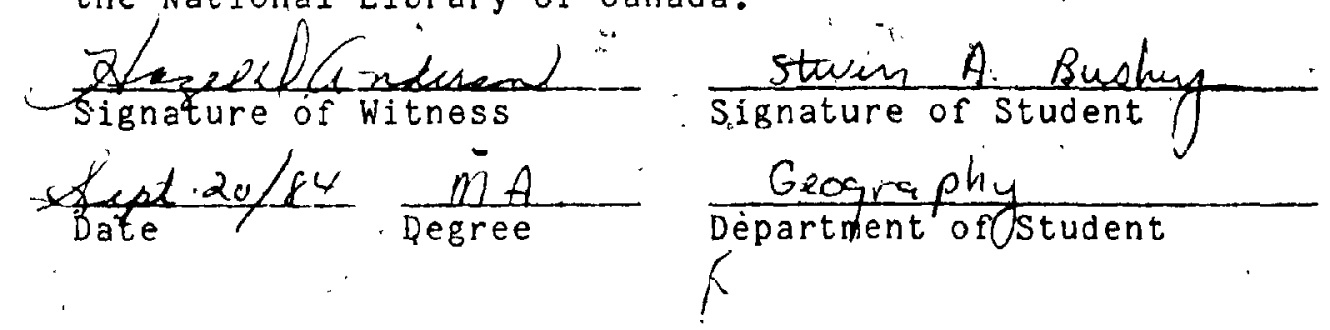
The undersigned recommend to the Faculty of Graduate Studies and Research acceptance of the thesis

"THE CATAMOUNT TRAIL:' aN INTRODUCTION, PROPOSAL AND FEASIBILITY , REVIEW"

submitted by Steve Bushey, B.A., University of Vermont

In partial fulfilmentof the requirements for

the degree of Masteir of Arts.

1
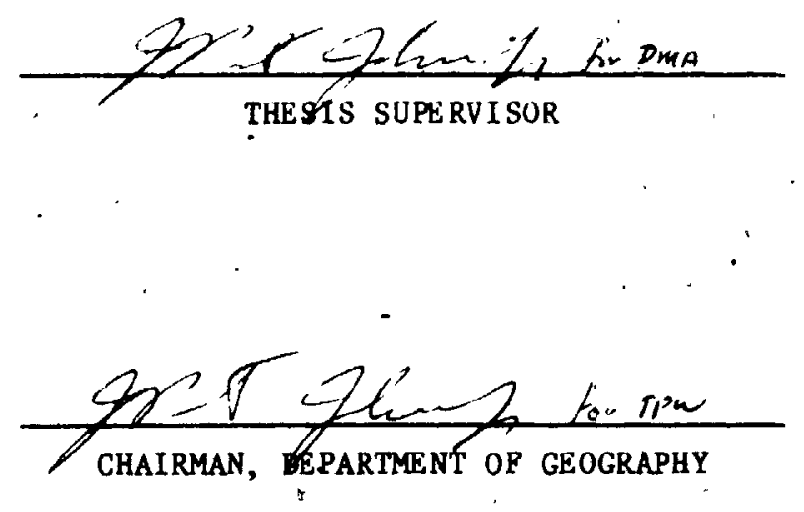

Carleton University

Sept ember 26,1984 


\section{ASSTEACT}

This thesis considers the potential for and feasibility of creating a vermont cross-country ski trail from the Massachusedts to Canadian borcer, similar in scope and concept to an existing hiking trail known as the Iong Trail.

Vermont's winter physical environment, characterized by * deep snows, falling over extensive highland terrain, is an ideal host for an already well developed cross-country ski recreation inf rastructure.

planning criteria and a methodology were formulated to identify the most feasible route for an "end to end" ski trail referredto as the Catamount Trail. The author and associates subjected the catamount Trail to rigorous testing, by skiing the proposed $260 \mathrm{mile}$ route in March 1984 . This testing confirmed research findings and generated recommendations for route improvements. The successful test trip following extensive research demonstrated the Catamount 'rail's high potential. 


\section{ACKNOWLEDGE]HENTS}

To Ben and Paul, for finding the time and going the distance. To Duncan, for valuable assistance and encouragement.

Bush

(3)

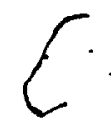

Ottawa, Canada

2 September, 1984. 
ABSTRACT .............................

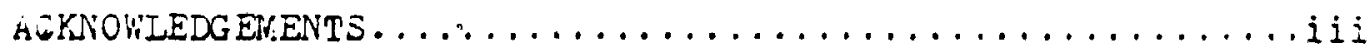

TABLE OF CONTENTS....................... iv

IIST OF FIGULEES $\ldots \ldots \ldots \ldots \ldots \ldots \ldots \ldots \ldots \ldots \ldots \ldots$ vi CHAPTER

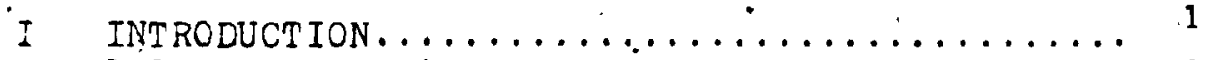

1.1 Introduction.................. 1

1.2 Cross-country Skiing Trends, . . .

1.3 Vermont Ski Centers and Trail

Networks.................... 4

1.4 The Implications of Inn to Inn

and Destination Skiing............. 6

1.5 Prior " ind to End" Trail Tradition

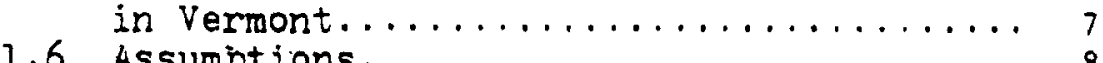

1.6 Assumptions .................. 8

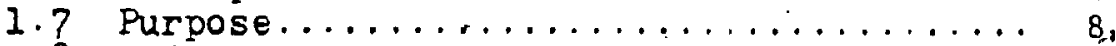

1.8 objectives..................

1.9 Methodology ................... 9

II GUTDOOR TRAIIS.................... 12

2.1 . Linear Trails in Outdoor kecreation..... 12

2.2 Planning for special Purpose

Linear Recreation Routes............ 15

2.3 Macro Criteria for Planning the

Route of a State Length Ski Trail....... 17

2.4 Data Sources and Research Methodology ... 24

III VEEMONT'S PHYSICAI ENYIRONMENT........... 30

3.1 Vermont's Physical Environment........ 30

3.2 Vermont's winter Climate........... 32

3.3 Terrain and Topography ............ 37

3.4 Vermont's Optimal Environmental

Ski Zone..................... 41

IV VERMONT'S WINTER RECREATION INFRAST RUCTURE. . . 44

4.1 Vermont's Winter Recreation

Infrestructure................. 44

4.2. Vermont Cross-Country Ski Trails........ 45

4.3 Vermont Cross-Country Ski

Touring Centres. ................ 50

4.4 Other Related Tourist Services............ 51

4.5 Iand Availability for Development

of. New Ski Trails................ 54

4.6 Green Mountain Cross-Country Ski

Infrastructure zone............... 59

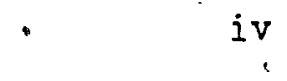




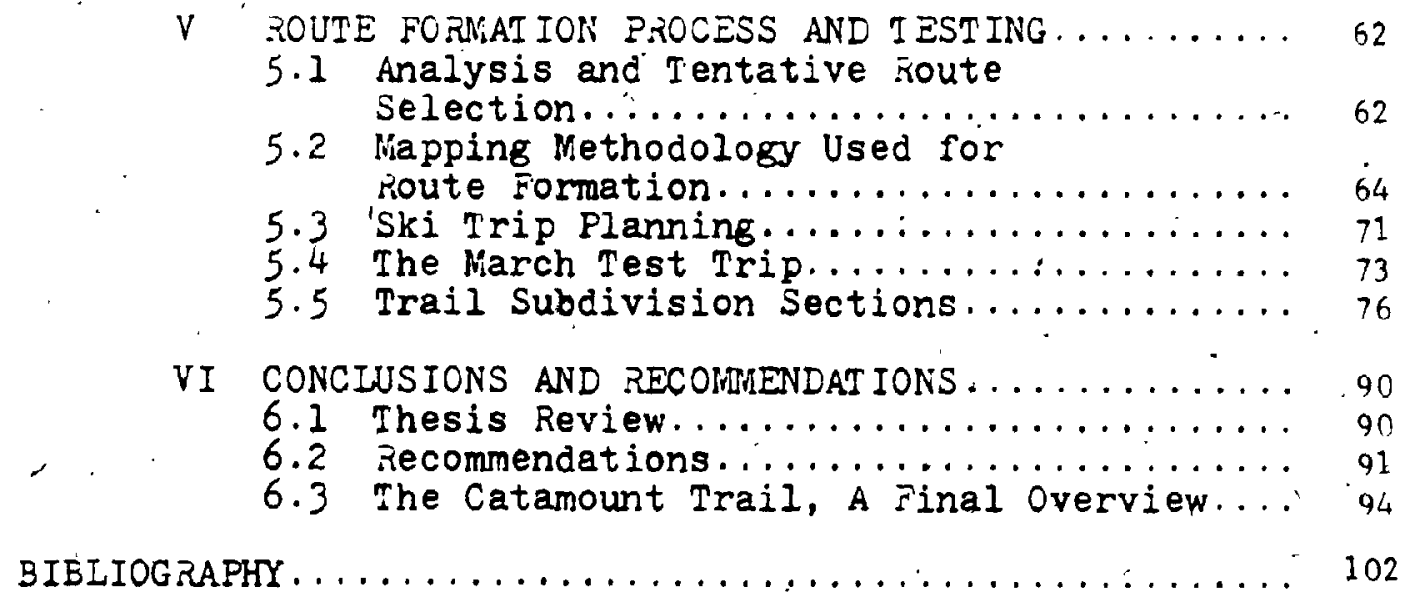

$\because$

$\mathrm{v}$

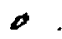

1 


\section{LIST OF EIGURES}

Figure

I PHYSIOSTRFHIC REGIONS...............

Figure

II VERMCINT MEAN ANNUAL, SNOWFALL ........34

इigure

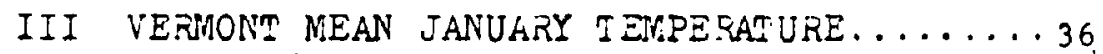

Zigure

IV VERINONT LAND HEIGHTS $\ldots \ldots \ldots \ldots \ldots \ldots \ldots 38$

Eigure

V VERMONT'S OPT LHAL ENV IRONMENTAL

SKI CONE..................... 42

Figure

VI SKI TOURING CENTERS $\ldots \ldots \ldots \ldots \ldots \ldots \ldots \ldots 47$

Eigure

VII 25 SKI TOURS IN THE GREEN MOUNTAINS..... 49

Figure

VIII' TOURIST RELATED SERVICES REGISTERED

WITH THE VERMONT TRAVEL INFORMAT ION

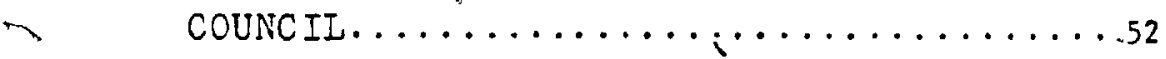

Figure

IX LAND IN FEDERAL AND STATE OWNERSHIP.....55

Figure

X. G.REIN MOUNTAIN CROSS-COUNTRY SKI* *

INFRASTRUCTURE ZONE. . . . . . . . . 61

Figure

XI CROSS-COUNTRY SKI INFRASTRUCTURE AND

OPI IMAI ENVIRONHENT AI SKI ZONES ......663

Figure. XII TUCKER HILI SKI TOURING CENTEE \&

MAD RIVER GLEN NOKDIC CENTRE.......68

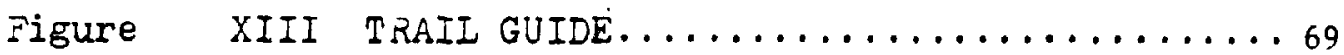

Figure XIV WAITSFIEID/MOUNT ELLEN TOPOGRAPHIC

MAP COMPOSITE................. 70

Pigure XV SOUTHERN VERHONI TRAIL SECTIONS AND NORDIC .

SKI AREAS $\ldots \ldots \ldots \ldots \ldots \ldots \ldots \ldots \ldots \ldots$

vi 
Figure, XVI SOUTHERN VERHCNI HIGHWAYS, TOWKS AND TRAIIS................ 79

Figure. XVII NORTHERN VERMONT TRAIL SECTIONS AND.

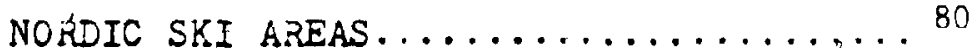

Eigure : XVIII NORIHERN,VERMONT HIGHWAYS: TOWNS AND TRAILS ${ }^{\prime} \ldots \ldots \ldots \ldots \ldots \ldots \ldots \ldots \ldots \ldots \ldots$

Figure XIX NOLTHERN VERNONT LODGES IN TOWNS ALONG THE CATAMOUNT TRAIL ......... 97

Figure $X X$ SOUTHERN VERMONT LODGES IN TOWNS ALONG THE CATAMOUNT TRAIL:........ 98 
Geographers in recent years have devoted considerable attention to outdoor recreation (Clawson; 1971; Marsh, 1982; Pigram, 1983; Wal1, 1979). In addition to research and theory building some have worked on a more applied level, spécifically, on the planning side.

Recreational land use tends to be either focal-(site - specific) or linear (corridor). This study is concerned with evaluating the feasibility gf a linear recreation corridor; that woild link specific recreation and service sites together.

The marked increase in affluence of North American society since World War II, has spurred an ever-increasing demand for outdoor recreational facilities, and placed increasing pressure upon the supply of outdoor recreational sites (Simmons, 1975; Coates, 1981; Lavery; 1971; Lindsay, 1983).. In particular, downhill skiing has enjoyea phenomenal growth during the post-war era. In the past two decades, there has also been an increase in the popularity. of crosscountry sking in both Canada and the United States. Fur thermore, certain patterns suggest that the nature of the sport is evolving into a demand for moré and different trail systems. The following study examines geographic aspects of this form of recreation and proposes a location and method for developing a new ski trail that is viewed as a consistent, cumulative and desirable maturation of cross- 
country ski trends in an area of high cross-eountry skiing popularity and potentiál.

\subsection{Cross-Country sking Trends, Popularity and Growth}

'Sking's roots can be traced to scandinavian countriek, where evidency indicates that skis were in use over 4000 years ago f(Heller, 1979: 20). During the later half of the nineteenth century skiing was introduced to North America by scandinavian immigrants. It was not until after world War II, in the late $1940^{\circ}$ s that skiing as a sport gained wide popularity. - In New England after World War II, there were slightly more than a dozen established downhili-areas. By 1978, some 150 areas were operating in New England serving three and a half million people according to industry estimafes ${ }_{i}$ (Rothafel, 1978: 9). In Canada, the downhill skiing. (alpine) industry had flourished, and by the 1971/72 season, Ontario alone contained 154 ski resorts within its" borders (Ontario Ministry of'Industry and Tourism, 1973: ii)

Cross-country (nordic) sking is the branch of. skiing that most closely resembles its historical roots as a centuries-old means of transportation! In, 1856 "Showshoe". Thompson demonstrated the utility of skis, in America when he "began to carry mail over the sierra Mountains in California on homemade, oak skis from Placerville to carson -Valley - a distance of 90 miles" SHeller, 1979: 21). By'

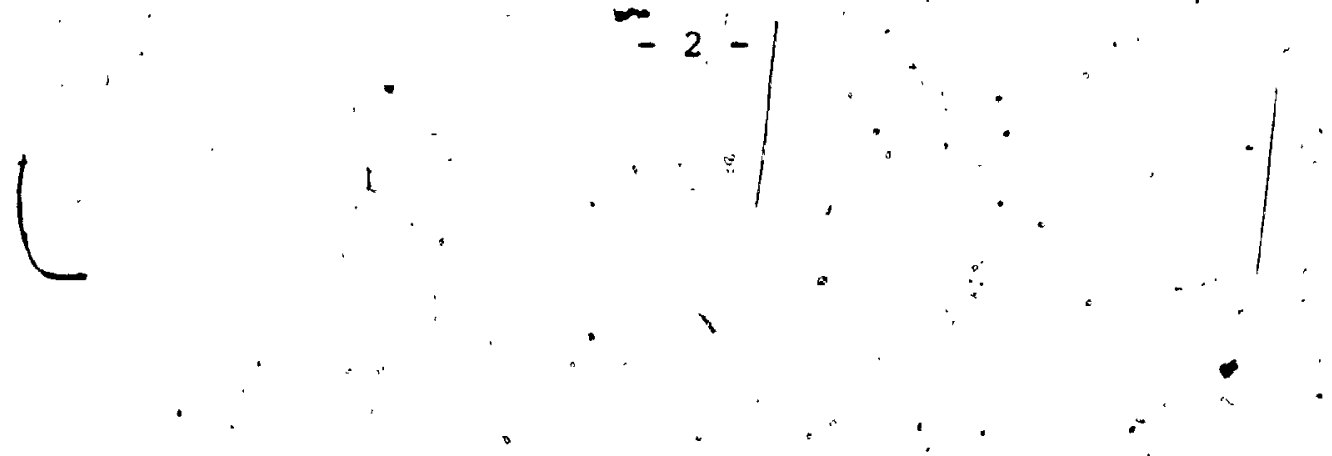


1900 regionaliy in Vermont, Northern New England, Central and Cordillera Canada cross-country skiing of "trail running", had beçome popular. From then until the ;

- 1960's the growth of skiing in terms of increasing demand, was far greater for downhill skiing than for cross-country. While downhill' sking overshadowed cross-country skiing across most of North America, in Quebec's fau'rentian mointains, the skiing visionary Herman "Jackrabbit" Johannsen was busy during the 19,30's pioneering and developing a new type of ski trail. He...

blazed and later cut the famous "Maple Leaf Trail." from Shawbridge to Mont Tremblant, winding through 90 miles of beautiful country. The trail was carefully mapped and skiers could plan to stay at the many hotels and hosts enroute. The weekend ski trains deposited/hundreds of skiers at villages along the trail (Anonymous, 1976: 1).

By the late 1960 's, indicators suggested that participation in nordic ski'ing was surging. U:S. Department of Commerce cross-country ski import ostatistics relate:

During the years of 1967,168 and, 69, a total of about 50,000 skis were imported; in 1970 alone, 50,000 , in 1971157,711 , in 1972 over 300,000 and in $1973,311,000$. While the import of downhill kis. declined, the skt touring imports steadily increased in 1974 and 175 . Further imports amounted to: $1976,360,000 ; 1977,550,000$; 1978, 770,000 (Ski Touring Council, Inc., 1979; 6)!

In Canada, over 1.3 million Candians had crosscountry. skied at least once during the 1975-76 season. Cross-country skiers had grown to outnumber "downhill skiers in every province except ontario, Alberta and British Columbia" (Statistics Cánada, 1976). 
By the mid 1970's, then, the popularity of crosscountry skiing was rapidly spreading across North America. one area particularly affected by this, growing interest in nordic skiing was the north-westernmost New England state of. Vermọt.

\section{.1.3 Vermont Ski Centers and Trail Networks}

The initial development phase of vermont ski areas and resorts started after World war II, when ski construction and development were oriented toward building an alpine industry. Vermont's high mountains, ample snowfall, and location between major North American cities, proved an attractive mix for investors and skiers. The factors that contributed to a successful alpine ski industry, have also helped Vermont to establish.itself as a premier American ski.touring state. The development and appeal of crosscountry skiing in Vermont has also been aided by the preexisting presence of a well-developed tourism and recreation industry. Now, with the sport's growth, not'only are cross-country skiers travelling to the older established tourist destination towns, but they are also, sampling "skiing hospitality in regions previously unvișited by tourists.

Most ski excursions before the advent of the ski cen-, ter were conducted through undeveloped fields or woóds, along logging roads, jeep tracks, unplowed town or country 
roads, or if the community was fortunate enough, over established cross-country trails created by a local club. While skiing of this type was suitable for area résidents, who knew the terrain and "trails", ski visitors often sought more guidance or instruction on where and how to ski. The 'Trapp Family Lodge in stowe sought to rectify this situation and opened the first ski touring center in America during the $1968 / 69$ season. The example set and lesson learned by the Trapp Family was that ski touring was an increasingly popular sport that attracted overnight sking guests and diners, a lesson that was not lost on others. The extent to which Von Trapp's successful ski center precipitated the growth of other state ski centers is a subject ôf debate. Inns, and lodges during the later 'part of the 1960's were probably beginning to recognize that a positive relationship existed between proximity to lodge skiing opportunities and.higher house occupancy rates. In any event, there were over 41 ski touring centers in Vermont by 1983 of which 28 .provided lodging arrangements, as listed in Northern Cartographer's Vermonf Ctoss. Country Ski Atlas (Bushey, 1983).

The trail networks created by these new ski.genters in vermont during the 1970's often borrowed sumer horse trails, jeep trails, hiking paths and unmaintained roads for their winter ski usage. This dual utilization of trails enabled ski centers to rapidly. develop ski networks.' sufficient in size to meet the skiing abilities of

$$
-.5-
$$


Americans, many of whom were just.learnịng to ski. With increasing skier experience levels and the maturing of cross-country skiing as a sport over the past decade and a half, many cross-country ski centers and skiers themselves began to find trail networks too limited. As skier proficiency levels increased, the "laverage skier" was able to ski further with less effort.

\subsection{The Implications of Inn, to Inn and Destination Sking}

The development of destination skiing, wherein one skis to a point or destination other than the starting place, has been stimulated and given added appeal in Vermount by inn. to inn skiing. Nearby inns have found it to their advantage to link and share trail networks, This exercise in co-operation, increases the number of ski trails available, to their guest at little extra cost: and allows the inns the opportunity to offer multi-night package ski tours. Stowe, Vermont is the best example of this lifnked trail network phenomenan, with over 100 miles of ski trails, linking, inns and four skì touring centers.

The evolution and development of Inn to Inn skiing in Vermônt raises the possibility of what Lance Tapley des-' cribes as a "Long Trail for skiers", in Ski Touring in New - England and New York (Tapley, 1978: 106). Trail networks have grown and interlinked over the past decade. As crosscountry skiing continues to gäin appeal, it is reasonable

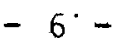


to expect that network linking trails will continue to be büilt. If this growth çan be coordinated, a state length. trail can be forged.

\subsection{Prior "End to End" Trail Tradition in Vermont}

Recreational "end to end" trail precedents have been established in Vermont for many years: The pest known example is the Long Trail, an "end to "end" hiking route 263 miles in length that traverses the Main Range of Vermont's Green Mountains from Massachusetts to Quebec. "The idea of the Long. Trail was conceived by James P. Taylor... After much preliminary work he called a meeting in Burlington on March 11, 1910.". (Ğreen Mountain Club, 1973: .5). It was not until 1931 that the final section of the Lorig Trail was cut through the wilderness. Since the completion of the trail over 1200 pepple have hiked the complete length of the state. The Green Mountain Club, responsible for the management and maintenance of the trail, has membership of over 3,000 perisons.

Vermont snowmobile clubs have been successful in the last two decades in creating, marking and maintaining a statewide network of snowmobile tratls. The Vermont Association of Snow Travellers (VAST) estimates that there are 10,392 miles of snowmobile trail in vermont. Of this total, only 113 miles have been built on national forest land and only 260 miles on state land; the balance of 
10,019 miles having been built on private land. VAST "corridor trails" run the length of vermont and are groomed for two-waỵ traffic (VAST, 1980; 7).

\subsection{Assumptions}

The following are basic assumptions which underlay this research and planning endeavour.

a) The state of Vermont has the appropriate physical and climatic endowments to permit establishment of an "end to end" ski trail.

b) The existence and location of Vermont's current ski touring centers and skiable trails are significant enough so that the development of interconnecting. ski links is a real and desirable possibility consistent with current trends of "inn to inn" or "point. to point" skiing.

c) Based on the popularity of other trail sports and the popularity of other "end to end" recreation trailsin

- Vermont, the identification of a potential-route for an' "end to end" ski trail in Vermont is both a desirable endeavor and a significant contribution to the field of outdoor recreation studies.

\subsection{Purpose}

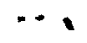

1

The primary purpose of this research is to explore ! and evaluate the feasibility of an "end to end" ski trail 
in vermont. An additional purpose is to alert others interested in vermont recreation to this potential develop-. ment. No evaluation of this type has been undertaken in vermont before. Thus this" study can serve as a valuable bașis for future studies and action.

\subsection{Objectives}

"The evaluation of the feasibility of an "end'to end" cross-country ski trail in vermont suggests the following objectives:

a) Reassess Vermont's natural resource base for crosscountry skiing, examining climatic and topographic factors in light of their potential for optimal routing of a continuous "end to end". cross-country iski trail.

b) Survey present ski touring centers, their trail networks and other existing skiable trails that might be used in the compilation process of forming a connected "end to end" trail.

c) Identify and evaluate a feasible route for an "end to end" trail the length of Vermont.

\subsection{Methodology}

a) The initial fesearch stage involved a review of the literature related to cross-country sking. Guidebooks, ski trail manuals and journal articles were 
examined. After the initial general review, material relating to vermont cross-country skiing and cross-country ski trail construction criteria were compiled to serve as a basis for future research. This review was complemented by field work and discussions with Vermont skiers who were able to verify, dismiss or explain questionable information.

b) Acting as editor and compiler at Northern Carto'graphic's Vermont Cross-Conntry ski Atlas during the summer of 1983, the author was able to collect cross-country ski maps that were later used to plot the rodte of the "end to end"'trail.

c) From the initial research, the criterion is for a long distance "end tó end" Vermont cross-country ski trail were established.

d) Using the established ski trail criteria, a reassessment of Vermont was undertaken to determine the most favorable geographic zone for development of an "end to end".ski trail. This zone was then delineated.

e) Úpon delineation of a most favorable ski zone, the locations of ski routes and ski centers which met the " physical trail requirements criteria lto formulate an "end. to end" trail), were charted onto detailed topographic. maps. An "end to end" trail proposal wascreated by linking together ski centers, ski trails and trailless stretches that demonstrated potential for future ski trail development. 
f) The proposed Catamount Trail*, (the name was assigned for convenience's sake and refers to the Vermont "end to end" ski trail proposal) was field tested by skiing the length of the state along, the proposed route.

g) The fiéld test results were interpreted and evaluated.

h) Recommendations for certin trail relocations were made to more fully satisfy the initial long distance "end to end" ski trail criteria.

This chapter has introduced cross-country skiing trends, the sport's popularity and growth. Inn to inn skiing and Vermont's "end to end" trail tradition have been reviewed. This study's assumptions, purpose, objectives and methodology have been stated. The next dhapter discusses linear trails in outdoor recreation. In addition it details a macro criterion for planning the route of a state-length ski trail ("The Catamount Trail").

* The "end to end" trail has been named after a mountain cougar, referred to in Vermont. myth and lore as the Catamount. The Catamount Trail shares with its namesake a preference for wilderness and highlands. 
Patmore (in Lavery, 1971: 72) defines the "fundamental spatial impact of recreation as being largely confined to lines of movement linking nodes of intense activity". Focal or nodal recreation concentrates user activities within boundaries that may be defined by landscape features or arranged by human design. Parks, playgrounds and resort centers are examples of designed nodal recreation sites, while beaches, waterfalls, scenic vistas, etc. are natural features which are $Q$ ften the focus of recreation activity. Recreational corridors or trails channel recreational activity over "lines of movement" that may be circuitous or linear, and which will vary for different modes of movement (such as motorized vehicle; bicycling, hiking, canoeing and cross-country skiing).

To clarify any ambiguity, "recreation Erails" will refer to routeways over which one travels while participating in an outdoor experience, where the journey becomes a critical component of the recreation activity. This term includes: scepic highways, horseback trails, hiking trails, canoe routes over waterways, snowmobile or ski trails, etc. " Recreation trails accommodate a flow of human activity. The process of movement may be aided by a motorized vehicle, such as" a trail bike, a non-motorized vehicle like a canoe or simply one's legs, as in trail walking: 
A common cháracteristic of all recreation routes is that they have origin (nodal) pounts where recreation activity commences, and end points, where it is discontinued. When a recreation trail system or trail possesses a closed nature, the origin and end points are one and same. In an open system, one has the opportunity to travel to a destination other, than where one started.

Linear routeways are a recreation resource for millions. They are recreation corridors with pointto-point user flow characteristics, which may accomotate the recreation preferences of many users, including hikers, motorists, boaters, canoeists and cross-country skiers.

In the past many linear routeways such as hiking trails and canoe routes, were designed for the specific use of a particular activity. Rapidly growing interest in trail sports and outdoor recreation has resulted in a greater number-of users, sometimes in conflict, where the demand for routes is placing increasing pressure on available trails. The united States Department of the Interior notes, for example, that "backcountry use in eastern National parks has tripled since 1967 and that there will be 4.4 billion walking activity occasions in the United States in the year 2000" (Lindsay, 1983: 1).

Many recreation routes serve as multi-purpose recreation corridors where several activities utilize the same trail, either simultaneously or on a seasonal basiș. The Gatineau Parkway, in Canada's National Capital region, is 
used in the spring, summer and fall by bicyclists and motorists for pleasure touring. With winter's árrival the roads are converted into ski trails, helping to make the park one of North America's largest ski touring areas. Linear trails characteristically have focal points inodes) of activity, "stopping places", where a variety of activities may be pursued. Points of interest, such as waterfalls, swimming holes, and historic sites along recreation routes usually generate localized activity. A waterfall and adjacent swimming hole will often attract picnickers, partiers, swimmers and photographers. Their joint use of a single area creates a node of activity. Such nodes often have service facilities to accommodate users.; pigram notes that the increasing popularity of trails has given rise to problems which affect design and mariagement decisions (Pigram, 1983: 59). For example, carrying capacity must be considered. What are the corridor environmental impacts of different use levels? At what point does user satisfaction decrease with increased use? Additionally, what type of conflict might arise when a single trail is shared by different users? In trail design there is a need for deciding beforehand, who the users will, be and what type of design and development criteria must be followed to best satisfy them. Without such forethought problems are likely to arise.

Recreation trails are conduits for recreation activity that have both a linear and mdal spatial impact. 
Increasing demand and use of recreation sites and routeways have led to conflicts between users of the same resource. These conflicts arise with crowding or overuse of a, resource and when alternative uses of a resource occur that are incompatible with the intended use. Many problems that trail managers and users face can be prevented beforehand by. proper planning which addiesses user needs and incorporates those considerations into trailway design.

\subsection{Planning for Special Purpose Linear Recreation Routes} :

Recreational geographers identify several issues that are of importance when considering any recreational development. Recreation may be either conflicting or compatible with current land use. Simmons (1975: 245) identifies three common themes that reoccur in contemplation of rural recreation resource management and development. Firstly, recreation must most often be consistent and coexistent with current land, uses, whether they be agricultural, nature conservatory, military land and water use or multiple. Secondly, recreation resources are vulnerable to overuse and deterioration of facilyties and surroundings. Thirdly, recreation ghtes have limited "carrying capacities"; if they are exceeded, ecological degradation and reduced "aggregate user satisfaction" result. 
Coates identifies User Conflicts on Recreation Trails

(1981: 3) as a primary trail management and development concern. His discussion revolves around multi-use of winter recreation trails, where conflicts between user's is

- "a function of numbers of user and number of contacts among unlike users. As user density rises problems develop. The compatibility of user groups is determined by physical and perceptual factors".

Guidelines that help minimize user conflict and environmental deterioration in the planning stage become useful tools later in maximizing the value of the recreation resource to its targeted users. While there are many existing ski trails in Vermont, an "end to end" trail design will have to Integrate selected established trails, where. they exist, into a singlé long linear route'. Vermont's total number of ski trails is considerable, but'trailess gaps will occur where new routes will have to be suggested to complete, the concept of a continuous trail. "In the process of selecting pre-existing trails for inclusion into

a greater length route and the process of recommending linkages between existing trails, the guidelines established by the ontario Ski council (O.S.C.) in their crossCountry Ski Trail. and Facility Design Manual (1980), for building cross-country ski trails, provide a comprehensive, well-thought-out set of criteria, and have been utilized in the route.layout stages of this study. The Ontario'ski council's 'guidelines cover in detail $-16-$ 
ski trail prelimunary planning needs, design and layout problems and solutions at the site level and trail construction techniques in addition to information on care and mantenance of established ski facilities and trails. These guidelines have been helpful for localized micro-site planning, trail setion and placement.

The proposed trail itself is a state-length macro route proposal and thus a"different set of criteria have been developed to establish the regional location of the trail. These macro-criteria reflect the concept of what an "end to end" Vermont ski route should offer.

2.3 Macro Criteria for Planning the Route of a Statelength $\underline{\text { Ski Trail }}$

2The quality of a cross-country ski touring experience is dependent upon the condition of the trail over which one skis, the environment through which one passes while skiing, and the activities and services available before, during and after' (apres) skiing. 'Thus the design needs of a linear "end to end" trail differ from the logistical, mechanical considerations required for proper on-site development of ski trails.

The following criteria werp drafted for the "end to end" ski trail study, to provide a means for evaluating and selecting existing ski trails and locating potential linkages for current trails, for their overall inclusion into 
a state-length route. This evaluation list is sensitive to the special needs 'of skiers and attempt's to minimize poten-. tial conflicts with other winter trail users. Such a checklist allows the planner to identify specific attributes and the overall attractiveness of a point to point route. The regions of vermont and the trails ultimately chosen for incorporation into the Catamount Trail, afe those which are thought to satisfy, to the greatest pos-, sible extent, the outlined criteria.

Ski Trail Criteria

1) Safety. In ski route design, safety should be a prime consideration. The winter climate is unforgiving when accidents occur. Skiers passing from point to point will often have to travel through wilderness tracts, often where no help would be forthcoming if needed. Trails selected for consideration should be well maintained in addition to being well and frequently marked, so that skiers will not get lost.' Trails should not be so steep that they might' cause a skier to lose control on descents or so narrow that a skier is in danger of crashing into trees. For macro... route planning, trails should traverse gentle and moderate: terrain and avoid régions where slopes are excessively steep.

2) Leng̈th of ski season. Though vermont is a small state, it possesses a surprising range of climatic variation within its borders due in part to elevation changes between 
regions. The amout of snow that falls within the state varies widely from region to region because of this. Any "end to end" ski trail should be routed through a weas that receive and retain maximum snowfalls. A longer ski seaison will permit and encourage greater use of this proposed. winter recreation resource and provide good. skiing during years when there is Iess than average snowfall. Ski trails at lower elevations which have reputations for short or unreliable seasons should especially be avoided.

3) Expected trail use. Ideally', the Catamount Trail should pass through areas that already have cross-country ski activity occurring. A trail that does, not receive " much use during the ski. season. may suffer somewhat in quaiity since it will be infrequently tracked and deadfali may not be cleared promptly from the path. A trail in a "skierless" region suffers most'during the off season, where it might be overgrown with brush and brambles. If no provisions are made for trail clearing and maintenance by a public or private group such as a ski touring center, Inn, ski club, citizen 'group, etc., the trail will eventually become overgrown with brush and virtually disappear. Public and private ski clubs, organizations and businesses are necessary to "provide essential support for any" trail, and if this support is absent then the longevity of the ski trail may be in question. Trail's routed through regions that attract few skiers may have a very short

$$
-19:-\because
$$


lifespan.

4) Availability of skier services and facilities. The pathway of the Catamount Trail should be designed so that essential skier services may be obtained without the use of a motor vehicle. In other. words, skiers should be able to ski to the door of the service centers, which, may include lodges, restaurants, ski shops, and, most importantly, cross-country ski centers which provide a complete range of skier services at one site. The following is a list of services and facilities that cross-country 'skiers cưstomarily seek.
a) Tracked ski trails
b) Ski instruction and lessons (including guide service)
c) Restaurants, grocery stores and supermarkets for meals, beverages and trail lunches

d) Inns, motels, lodges, etc., for overnight accommodations
e) ki shops for equipment purchase, rental and repair
f) Entertainment and nightlife

5) Trail difficulty. The Catamount Trail should be routed over easy and intermediate trails where and whenéver possible, rather than difficult or most difficult routes. Easy trails provide enjoymerit and challenge, for all levels of skiers, from novice to expert, whereas difficult trails can be enjoyed by anly a smali sector of the 
skier population. Dhfflcult trails also present the prob1 lem of becoming dangerous under less-than-favorable snow and weather conditions. Intermediate tracts can easily become "difficult" when icy. "Difficult" trails, when icy", become treacherous.

6) Land availability and accessibility. This criterion is related to land ownership. Land ownership in Vermont can. be subdivided into' three general groups: public, private and corporate. The Catamount Trail when possible should be located on publicland. Recreation developments on public land are far easier to co-ordinate and maintain than on private land. Fortunately for the trail proposal, much of the region which appears to be most viable for ski trail development, the Green Mountain Regian, is owned by sizable. public agencies, the largest' two being the Federal and State Forest Services. Conversely, private land should be avoided as far as possible, especially in the light of the current trend toward increased land posting ${ }^{*}$ around the state.

7) Minimal trail development expense and-effort through maximal use of existing facilities and ski routes. The Catamount Trail proposal is more an effort to co-ordinate and consolidate current ski trails and facilities into a linear route than it is an attempt to create a whole new ski trail. It is not necessary to duplicate current cross * where trespassing is prohibited. 
country ski resources, but rather to integrate them in a coherent manner. As with most public projects, those that. are likely to be most feasible are those that promise the greatest return for the least expense. The creation of trail links between existing facilities and $5 k 1$ routes in acceptable/suitable areas is the main development focus of the project.

8) Avoidance of trail use conflicts. Trail use conflicts between recreationists often occur when a single trail is shared simultaneously by two or more trail users. Snowmobilers and cross country skiers have had an uneasy history of sharing winter snowtrails. When the degree of shared trail use has been high between these groups, conflicts have occurred. There are many arguments for maintaining separate trail systems, for these users, but in the absence of such systems in any area conflicts may continue. to occur.

Coates notes that:

The skier is truly compatible only with other skiers... Multiple-use of winter trails is a myth perpetuated by public land managers who do not understand the realities of the activities involved (Coates, 1981: 3).

In Vermont, the traditional winter trail conflict has been between snowmobilers and skiers. This conflict appears to be waning, due to decreasing snowmabite-use and : increasing respect and.acceptance of the rights and activities of each trall-using group. In Vermont, there are 
grounds for sharing some trail resources. The many public highways and national forest roads that are left unplowed during the winter months are not ideal routes, but are wide enough to be safely shared by both user groups without engendering any conflict.

In order to avoid trail use conflicts with other trail recreationists, the catamount Trail will be planned fo use as many cross-country ski trails as possible, ang public or forest service unplowed roads when necessary. The use of existing snowmobile trails is not favored. The design considerations of the Catamount Trail have been constructed to serve the needs of cross-country skiers and no compromises or concessions have been introduced that favor the needs of other traij using groups at the expense of nordic skier safety or pleasure.

In conclusion, the design considerations that affect the placement of the Catamount Trail are related to the following criteria:

1) skier safety

2) length of the local ski season

3) moderate or above-average volumes of trail use expected

4) trailside availability of skier servioes and facilities

5) easy: to moderate trail difficulty

6) preference for trail routing through public land

- 7) low-cost trail development using existing facilities and ski trails. 
8) avoidance of trail use conflicts with other winter recreationists.

The trail criteria listed represent a somewhat idealized view of the "best" that an "end to end" Vermont ski trail might offer. There are cases, where it will be impossible, to satisfy the whole set of criteria for given regions of the state. Vermont offers many options for 10cating $a$ state-length trail and the ultimate trail location will, to the fullest extent possible, satisfy the demands of the preceding criteria.

\subsection{Data Sources. and Research Methodology}

The resources used to develop and document this routeway feasibrility study can be subdivided into the categories of literature sourcés, cartographic resources and personal information interviews. The most general literature resources used provided background on vermont macro. climatic and topographic conditions. The Country Journal's New England Weather Book (1980) provided information on Vermont weather and the location of the state's heavy winter snowfalls. The Geographic Regions of Vermont (Meeks, 1975), proved to be a valuable reference containing text and maps relevant to topics covered in this study.

The best single contemporary vermont recreation information source is the State Comprehensive Outdoor Recreation Plan 1978-1983 (SCORP) by the vermont Agency of 
Environmental Conservation. The SCORP report reviews in detail Vermont's natural resources, recreation resources, winter activities and recreation economics. Other valuable state documents used in this study include a series of memoranda and reports originating from the Vermont Department of Forest, Parks and Recreation, which discuss the feasibility of creating a "Low Lands Long Tfail", which in some respects resembles the concept of an "end to end" ski trail.

Cross-country skiing guidebooks were very helpful in locating existing Vermont ski trails and ski facilities, and aided in the formulation of criteria for developing a statelength trail. Ski guidebooks can be subdivided into two categories, those concentrating on teaching techrique and those concerned with where to ski, which are more geographical in nature and of greater relevance for this study.

The Ski Touring Council's Ski Touring Guide (1979) reviews skiing places around North America. However because, it is so broad in scöpe, its reviews are brief and of limited value. Lance Tapley covers a limited number of ski areas in Vermont with 13 pages in his ski Touring in New England and New York (1978): In describing his 1969 cross-country ski journey that consumed "14 days in January and February skiing the length of vermont, going from the Massachusetts border in Guilford to the Quebec line at Richford", a distance of slightly over 200 miles", Tapley 
develops a case for creating a."Long Trail for Skiers". Lousteau's Guide to the Ski Touring Centers of New England (1980), reviews 39 Vermont Ski Touring Centers with written passages. The information is dated since some 1 centers have ceased operations. The Eastern Mountain Sport's Ski Touring Guide to New England (1979), while providing over 50 written descriptions of Vermont ski trails and centers falls short by providing only one map.: Sally and Daniel Ford's 25 Ski Tours in the Green Mountains (1978), provided maps of each described ski tour. With this arrangement ski trails could easily be transferred to topographic or other working maps for planining purposes.

Stanton Allaben's Vermont Ski Trail Guide - South Central Region (1982), and Vermont Ski Trail Guide - Central Region (1983), provided written trail descriptions and ski trail maps printed over somewhat faded reproductions of U.S.G.S. topographic maps. These guides were very useful in pinpointing the exact location of numerous state ski trails.

The Ontario Ski Council (O.S.C.), in Cross-Country Ski Trails and Facility Design Manual (1980), furnishes ski industry accepted guidelines for defining topographic and climatic conditions favorable to cross-country ski development. The standards established by the council were followed as often as possible in the "end to end" route selection process. Used in conjunction with the O.S.C. manual was the Vermont Association of Snow Traveler's (VAST), 
Vermont Snowmobile Tralls Manual (1981), which discusses their successful methodology for securing private landowner co-operation in trail development projects. While snowmobiling and cross-country skiing are different sports, the challenges and problems of trail development, including trail design specifications faced by both groups are somewhat similar, making this manual a valuable planning. source.

Stanton Allaben's two part article "Public Lands Provide Unlimited Potential for Ski Trails" in successive is- * sues of Nordic Skiing (October and November, 1976), detail the development process of creating a public ski trail network in the Green Mountain National Forest of Southern Vermont.

Additional research material was gained for this study by the author, acting as editor and compiler of Northern Cartographic's Vermont Cross Country Ski Atlas (1983). The completed atlas covers 41 vermont ski centers with a map and written information for each center. The atlas compilation process started with the Vermont Travel Division's brochure Cross Country Skiing Vermont A Special World, which listed $58 \mathrm{ski}$ centers in the state. These ski centers were personally contacted by mail, by telephone and in person to verify and add to the initial state supplied information. By the end of summer, 1983, via this process, over three dozen ski touring center trail maps had been collected, which later proved invaluable in planning 
the propose route of the Catamount Trail. Personal contact and interviews with ski area representatives during the summer helped to verify information, and these persons also provided some valuable insights on route problems. The single most valuable landscape information resource available to geographers is maps. Vermont topogra-. phic maps published by the United States Geological Survey at the scales of $1: 62,500$ and $1: 24,000$ were the map scales most frequently used. In several cases out-dated maps proved to be a liability, which was circumvented by using 1978 and 1980 air photographs $(1: 5,600)$. These provided exceptional detail and̆ clàrified land-use questions.

The Catamount Trail literature, map, and informationsource review process, sought information about vermont and Vermont cross-country sking at several different scales, , ranging from general small-scale to detailed large-scale. General information extracted from sking guidebooks was the first stage in, the research process that led to a more intensive search for more detailed information.

While readily available ski center cartographic information was sometimes less than accurate, it was possible to cross check questionable data with U.S.G.S. topographic maps, or to phone or visit knowledgeable skiers to clarify questions. The sources related to cross-country ski trail information were ample but diffused. Without this abundant supply of information, "the Catamount Trail proposal would have been far more difficult to develop. Almost two dozen 
ski touring center trail maps were used in conjunction with as many U.S.G.S. topographic maps to draft tre initial route proposal. The amount of information which was available, albeit from a diversity of sources, testifies to the maturity of cross-country sking in the state of veriont. 


\subsection{Vermont's Physical Environment}

- Recreation resources for cross-country skiling can be

- divided into two categories, bio-physical environment and the built- (man-made) environment. Vermont's bio-physical environment derives its uniqueness from the continuing interaction betweeñ topographic features, climate and biosphere, the elements which constitute the natural envirionment. The built environment is distinguished from the physical, in that it is the product of $\operatorname{man}^{4} s$ activities: Outdoor recreation resources generally reflect a combiriation of the physical and built environments. This study seeks oto examine and assess the physical and developed recreation resources within Vermont essential for creation of a long distance cross-country ski trail.

Vermont is one of the smallest of American states, less than half the size of Nova Scotia and slightly larger than. Wales: Nonetheless, it has a physical environment notable for its variety. The vermont Geological Survey (1961), recognizes six distinctive physiographic regions within the state Isee Figure I, Physiographic Regions map, Méeks, : 1975: 24). Each region is a particular physical landform with distinctive characteristic terrain, climate and veget: tation. The purpose of this chapter is to identify, the physiographic region, or combination of regions (zone), that possess. the most favorable environment and physical characteristics within the state for the, development of a

$$
g^{-30-}
$$




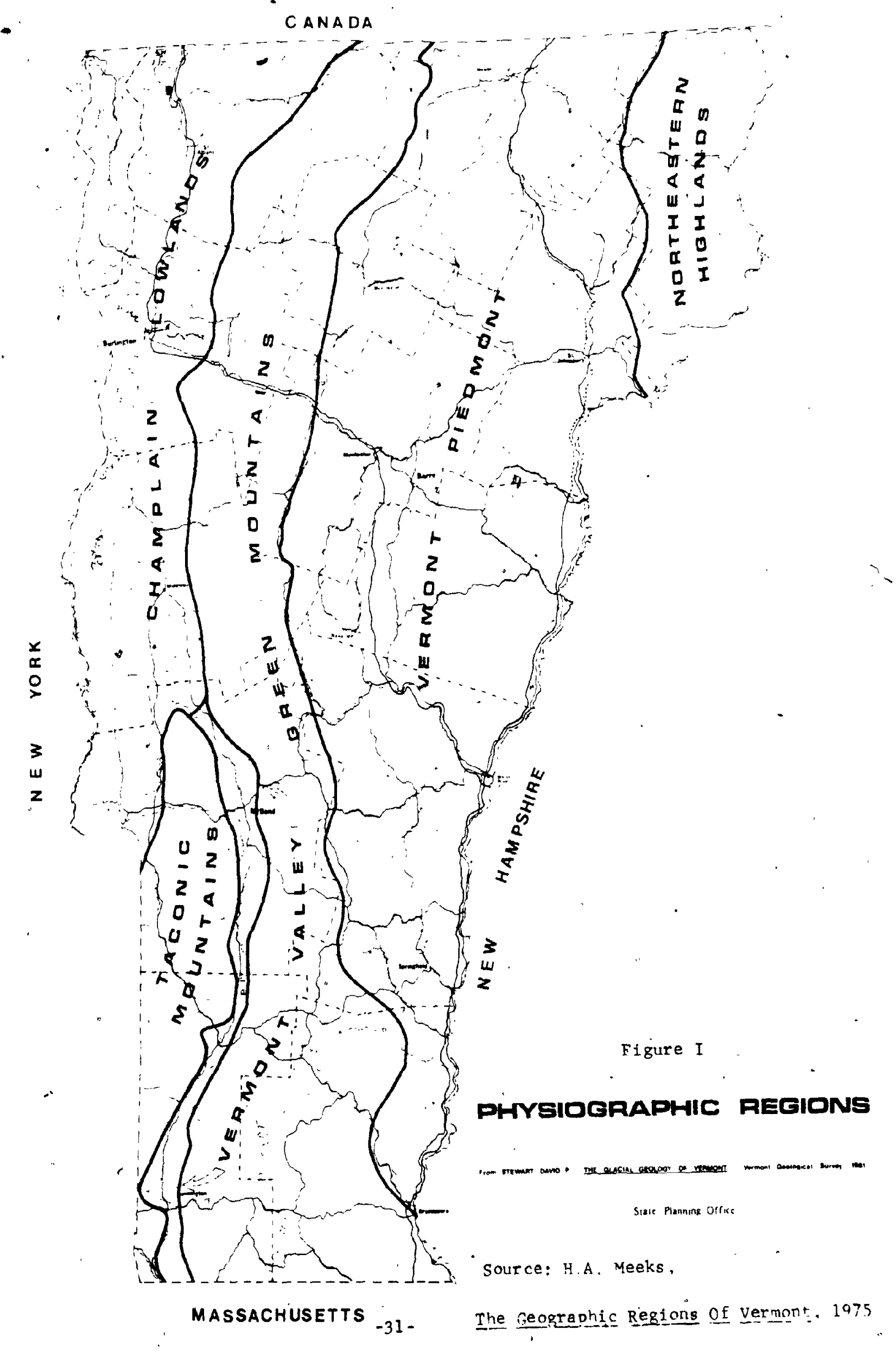


linear "end to end" ski trail.

The Ontario Ski Council (1980: 6-10) recognizes that cross-country ski areas must establish themselves within areas of suitable climate, terrain and landscape to be successfui. The following sections of this chapter characterize and identify the physical environment most suitable for cross-country skiing in Vermont. Cartographic analysis of Vemont's climate (section 3.2), terrain and landscape (section 3.3) lead to the identification of an optimal environmental ski zone (section 3.4).

\subsection{Vermont's Winter Climate}

Adequate snowfall and retention thereof are primary concerns for any ski, trail development. Vermont's pattern of winter snowfall demonstrates that within the state there is a sizable "snowbelt" that has substantial potential for skiing, receiving a yearly average of more than 80 " of snow.

Vermont is the only state, in New England without a seacoast, but its winter climate is determined by the properties of both continental and maritime air masses. The continental air masses are generally dry' and cold, but they yield frequent snowfalls'. The maritime weather systems

- which are responsible for many of the state's heaviest sriowfalls (12" or more) have a greater influence in Southern Vermont, because it is closer to the storm centers 
which tend to lie off the New England coast (Ludlum: 1976: 8-iil.

Examination of the Vermont Mean Annual Snowfall map (Meeks, 1975: 30r in Figure II indicates a correlation between the location of the Green Mountains' (see Figure I) and the zone of heaviest mean annual snowfalls. This "snowbelt" stretching from Massachusetts to Canada, can be attributed to the phenomenon of orographic snowfall. Orographic snowfall is caused by mountains that stand in the path of moisture-laden air, which is forced to rise and cool as it pásses over the mountains. Snowfall results when the water vapour content is sufficient and the temperature is below freezing (Moore, 1979: 159). The configuration of the Green Mountains, standing as an almost unbroken'north-south wal1 '2000' to 4000' above vermont's western lowlands serves to amplify the impact of orographic precipitation, as the mountains act as a barrier to the prevailing west-to-east air flow.

The Vermont Mean Annual Snowfall. (Figure II) map is a generalized portrayal of state snowfall patterns. The data base for the map was collected from reporting stations 10cated in towns generally below 1000'. Because of this lowelevation bias, the map probably tends to understate the average annual snowfalls that actublly descend in the highlands and mountains. Despite suoh limitations the map does demonstrate the location'of the state's Green Mountain snowbelt, an area which, on average, collects mare 


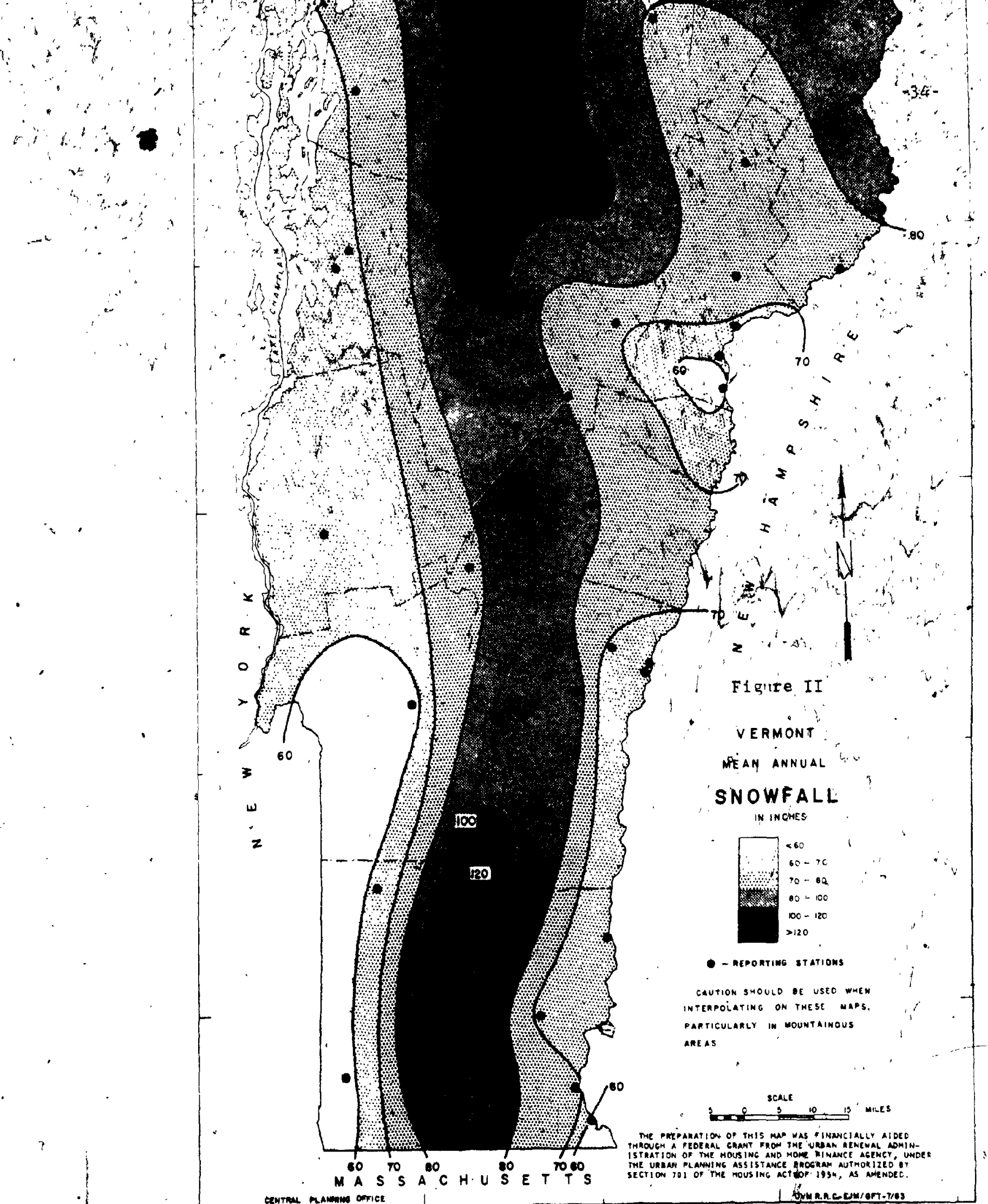

centrat maneme orreter

Source: H.A. Meeks, The Geographic Regions of Vermont, 1975. 
than 80" of snowfall a year.

The areas within the state that are most' capable of retaining snow once it falls are those areas with colder average climates. The Vermont Mean-January Temperature map (Meeks, 1975: 28) in Figure III, indicates that an area known in Vermont as the "North East Kingdom" is the coldest part of Vermont during January, with average temperatures of less than $16^{\circ} \mathrm{F}$. A long finger of cold air (18 $\mathrm{F}$ or less), hoversj over the Green Mountains, penetrating almost to the Masisachusetts border. The actual temperature conditions to be found in the mountains are probably colder, but it is currently impossible to present a more precise temperature regime for the state due to the limited number of reporting stations.

Cold average air "temperatures and a belt of heavy. snowfall cover the Green Mountains during the winter, making it the area most resistant to snowcover loss during "New England's unpredictable."winter thaws". The benefits of heavy snowfall, cold temperatures and resistance to thaws have made the Green Mountain physiographic region a most favored climatic zone for both alpine and nordic skiing. The following section (3.3) further explores the relationship between climate, elevation, terraif and ski area locational preference in order to define the area that can be classed as optimal for an end-to-end cross-coutry skiiing route: 


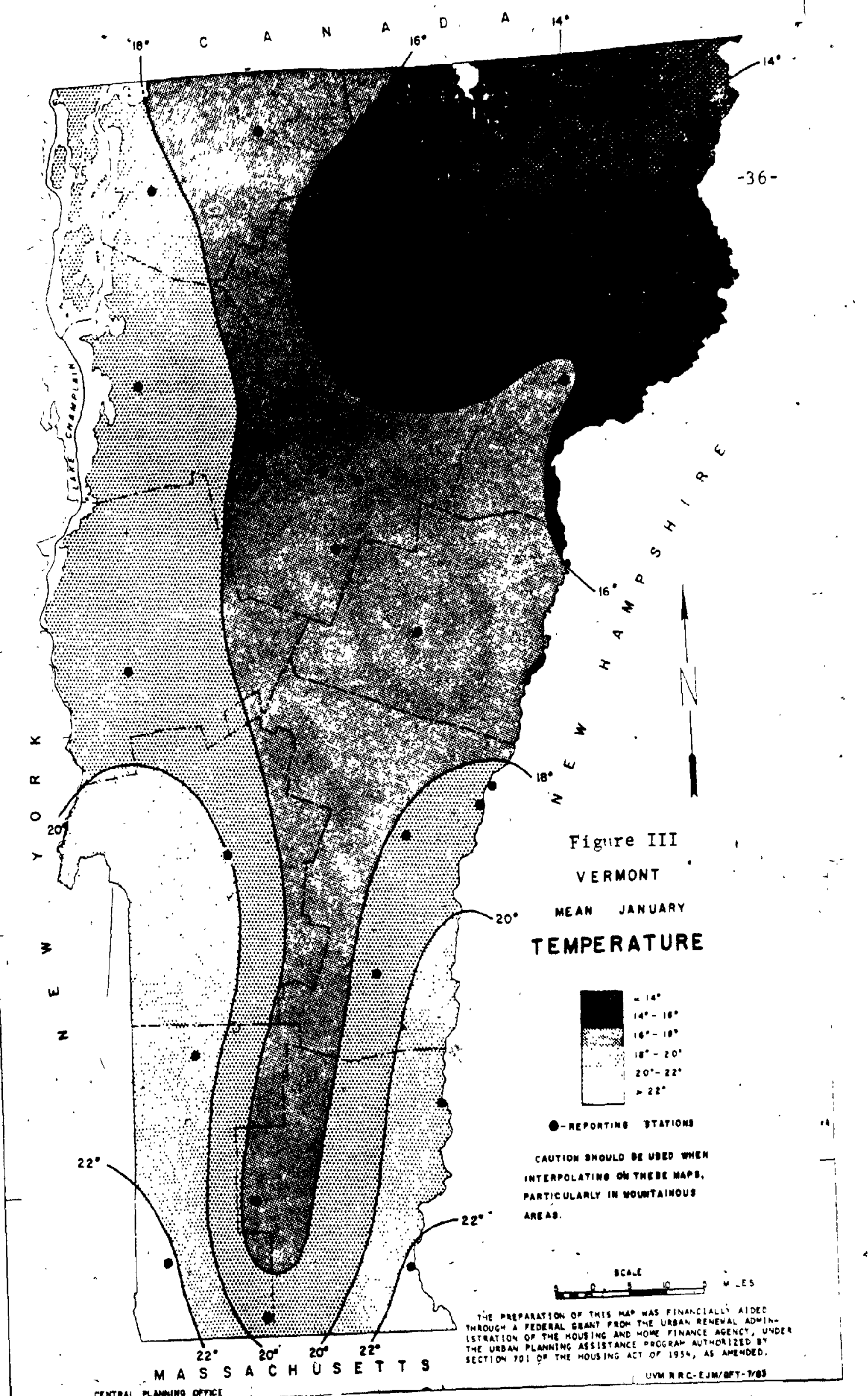

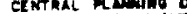

Source: $H$ A. Meeks, The Geographic Regions of vermont. 1975 


\subsection{Terrain and Topography}

The primary landscape factor that affects the location of cross-country skiing activity in vermont is elevation. Slope steepness and slope exposure to sun and wind also affect the favorability of iandscapes for cross-country ski

- use. Furthermore, the relationship between elevation, steepness, and slope exposure will affect the "skiability" of any area, as it has a bearing on the amount of annual snowfall received, the amount of snow retained and the overail length of the ski season.

Comparing the Vermont Meañ Annual Snowfall map in Figure II and the Vermont Land Heights map (Meeks, 1975: 14) in Fiqure IV, there is a noticepkle correlation between. the higher elevations of the Green Mountains and the amount of snowfall received. The mountains fometimes receive more than 60" of snowfall per year above that received at lower elevations to the west. This pattern can be partly attributed to the inverse relationship between elevation and temperature, called the environmental lapse rate (the rate at which air cools with increasing altitude). Though dependent upon atmospheric conditions and moisture, the lapse rate is generally in" the range of $3.5^{c} \mathrm{~F} / 1,000^{\prime}$.

The elRvation variation between Vermont's largest city df Burlington (which is situated on the shore of lake Champlain at $95^{\prime}$ elevation) and two nearby cross-country ski centers, Bolton Valley $\left(2000^{\prime}\right.$ base and 19 air miles 


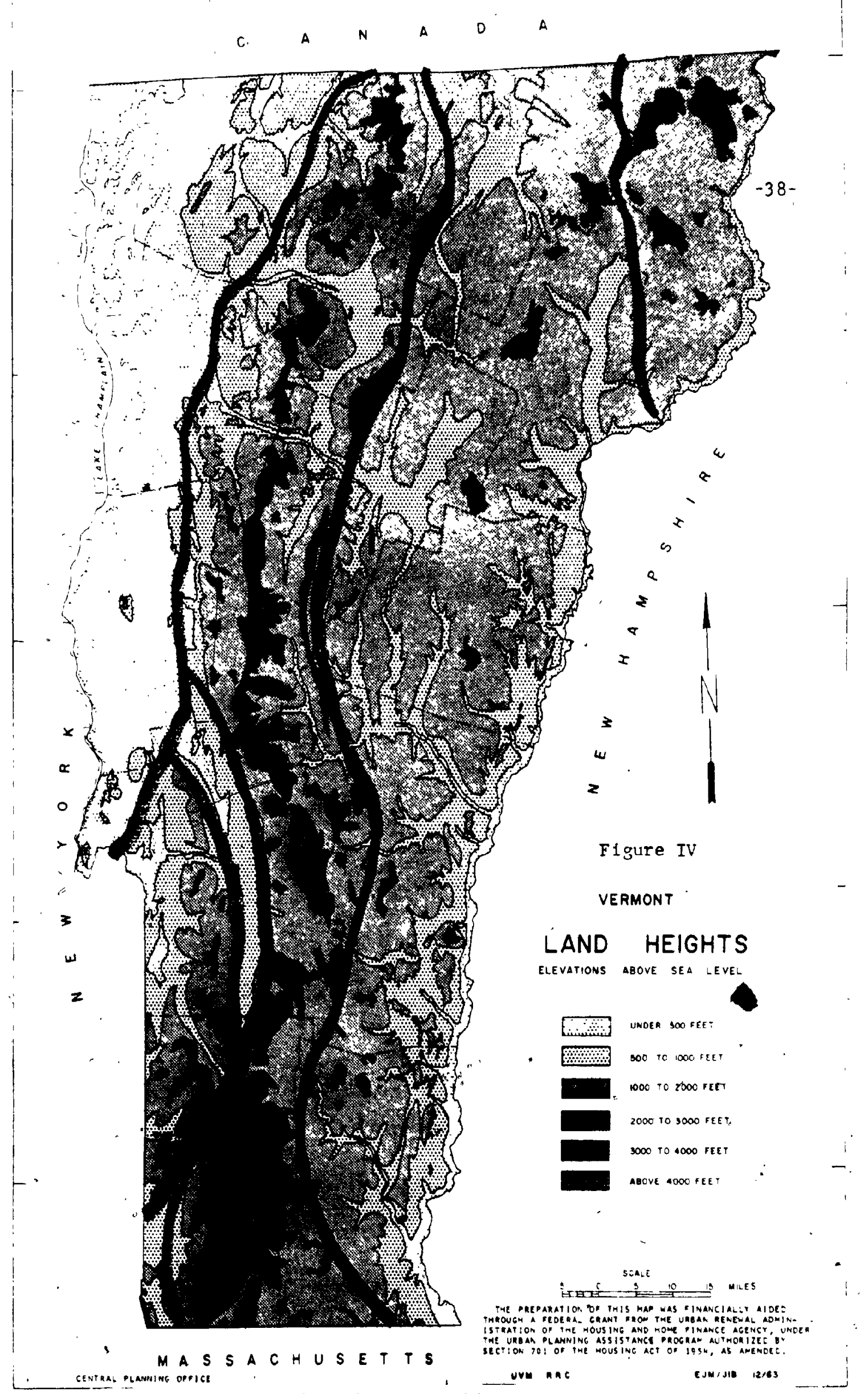

Sourre: भ.A. Meeks, The Teographlc Regtons Qf Vermont, 1975 
east-southeast) and Trapp Family (1350' base and 23 air miles east) is substantial. Because of the lapse rate, temperatures at these ski areas under normal conditions can be 7 and 5 degrees $F$. cooler than in Burlington, respectively, often the difference between precipitation occurring as rain and addịtional snowfall.

Statistics compiled from the Vermont Cross Country Ski Atlas (Bushey, 1983), reveal that the 41 listed ski centers are generally located at elevations above 1000'. Only $27 \%$ of the listed ski areas operated from a base lodge below 1000', while 178 operated, at elevations from 1000-1199', and more than half $(56 \%)$ operated from base elevations of $1200^{\prime}$ or higher. Of the 10 highest ski centers, 1600' or higher, 9 were located in the Green Mountain Region. As there is a strong correlation between elevation and cross-country ski center location, there is also a correlation between ski area location and physiographic re- . gion. Predictably, the Green Mountains, with the state's highest elevations, have $66 \%$ of the cross-country ski centers within their area. The vermont Piedmont, with 19.58 of ski touring centers is a distarit second. The combined total for the rest of the state, including the Taconics, the Northeast Highlands, Vermont Valley ard the Champlain Lowlands (see Eigure III), represents a meager 14.58 of the state's ski areas.

The tendency for ski area operators to establish at elevations above a $1000^{\prime}$ helps them to minimize the impact 
of a disastrous thaw and maximize the number of ski days per season. The ski centers under $1000^{\prime}$ often survive because of their proximity to skier generating sources such as large urban centers, depending on volume to compensate for shorter ski seasons.

One prohibitive aspect of locating ski trails at higher elevations is that slope steepness may 2 ncrease with elevation. Because of these circumstances, many of Vermont's ski trails and ski centers have located halfway between the mountaintops and valley bottoms, at high elevations, yet in gentle or moderately sloped terrain.

- Slope exposure to excessive sun and wind is an environmental detriment to good skiing conditions. South facing slopes lose their snow earlier than north faces, because of increased exposure to solar radiation: If located with proper exposure a trail can be made skiable for many extra days. Since the Green Mountains intercept the prevailing winds, snowloss on the windward (west) side of the range due to sun melting and wind drifting can be expected, whereas the leeward or east slopes tend to collect this blown snow. This pherromenon is most noticeable near the. ridgelines of the Green Mountains, where huge drifts often occur immediately over the ridge on the lee side: Most Vermont ski areas have located their ski trail networks on terrain with slope faces that minimize wind and sun problems. In particular, 19 of the 27 ski centers (70\%) found in the Green Mountalns have located where snow 
conditions are more favorable, to the east of the Long Trail (which follows the crestiine of the Main Range, the highest ridge of the Green Mountains). The Green Mountains, with higher-than-average elevation and snowfall for the state, contain 668 of all Vermont ski areas, The Green Mountain terrain east of the Long Trail shelters 19 of the region's $27 \mathrm{ski}$ areas from the snow depleting affects of excessive wind and sun exposure that occurs with greater frequency on the range's western slopes. The location of so many of vermont's cross-country ski areas within the Green Mountains is no accident. The area is clearly a zone with advantages of terrain, topography and climate.

\subsection{Vermont's Optimal Environmental Ski. Zone}

The primary physical environmental factors that positively affect the potential of cross-country sking in Vermont have identifiable spatial regions. One can designate; by mapping, where these regions overlap, a zone of optimal environmental ski conditions. This zone is defined by three criteria - the overlap of the more sheltered (from wind) and shaded (from sun) Green.Mountains east of the Long Trail, areas where snowfall is annuại in excess of $80 "$, and where land elevations are above 1000'.

The, map in Figure $V$, Vermont's Optimal Environmental Zone, plots the area where the three criteria overlap. 


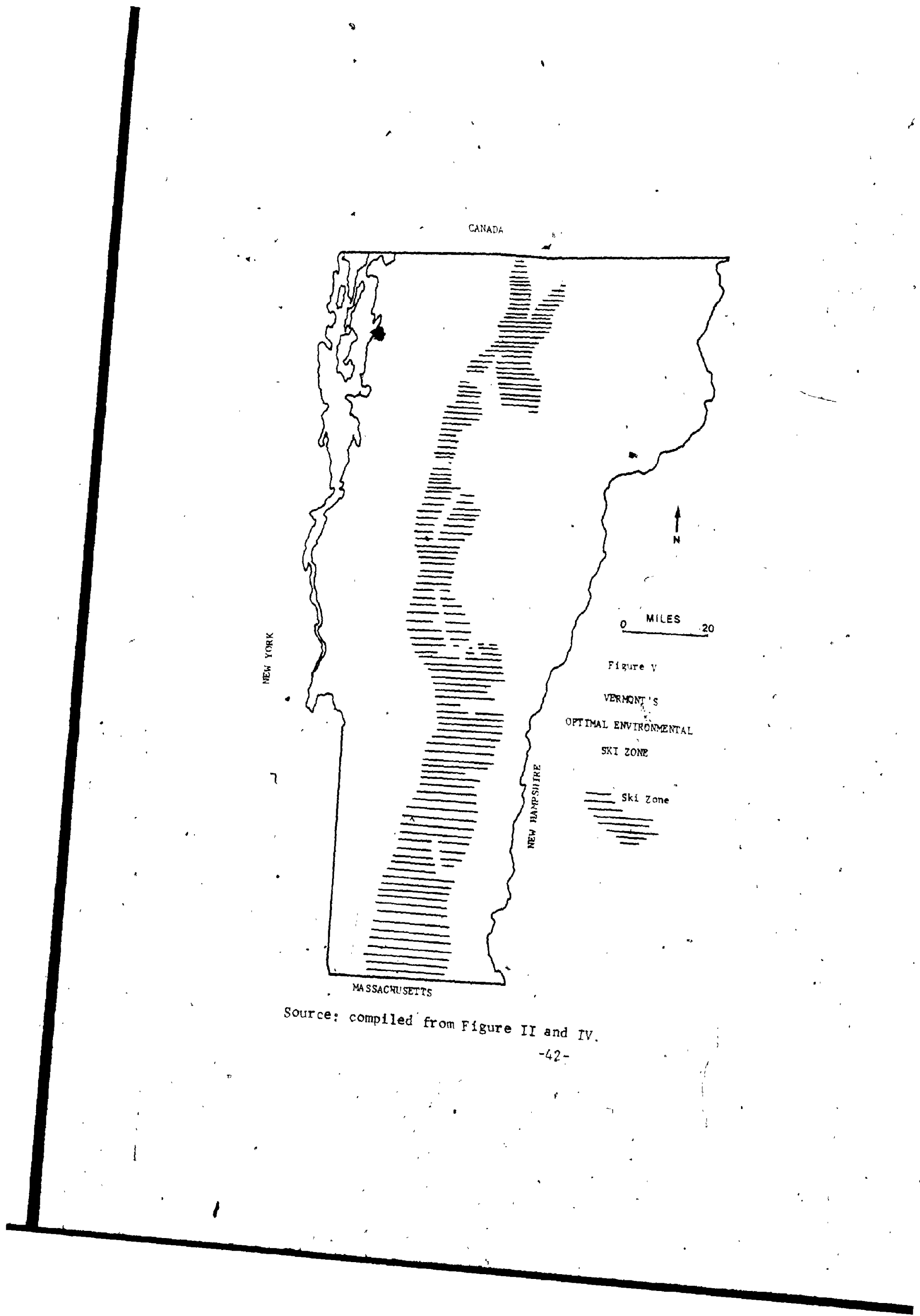


Three characteristics are noticeable in the pattern of this zone. First, the zone in the Southern third of vermont is very wide. Secondly, in Central and Northern Vermont the zone narrows and is often indented by river valleys on the eastern side. Thirdly, the continuity of the zone is twice interrupted in Northern Vermont by the low lying' Winooski and Lamoille Rivers. In order to avoid the frequent river valley interruptions that occur on the eastern portion of this zone, development should focus whenever possible on the central and western portions of this optimal environmental ski zone.

This zone has a high territorial.correlation with the Vermont Green Mountain physiographic region, which in turn correlates with the location of many of Vermont's existing ski touring centers. In the interest of maintaining high quality skiing conditions, the Catamount Trail should be routed through the optimal ski zone, when and where circumstances permit. Already, there has been a concentration of man-built recreation resources within the optimal environmental ski zone. The next chapter discusses the developed recreation infrastructure that exists within and adjacent to the Green Mountains and it's relationship to an "end to end" ski trail. 


\subsection{Vermont's winter Recreation Infrastructure}

Chapter III has defined the geographic location of Vermont's optimal environmental ski zone. This zone con-: siderably overlaps the Green Mountain physiographic region, within whichit has been noted that two-thirds of Vermont's cross-country ski areas are located. This chapter will'. survey and identify winter recreation resources that exist within and adjacent to the optimal environmental ski zone. While there are winter recreation resources located outside the optimal environmental zone they are seen as less than desirable for inclusion into an "end to end" ski trail since they would violate the ski trail standards established in chapter section $2.3(2)$ regarding the length of the ski season. This measure concentrates the infrastructure identification process on the central mountainous portion of Vermont.

Vermont's winter recreation infrastructure might be defined as those constructed and maintained services and facilities of significance to cross-country skiing and skiers. Specifically, this chapter defines the location of Vèrmont ski trails, ski touring centers, ski lodging and hospitality services and finally, the important issue of land availability for the development of new ski trails, and facilities.

This chapter like the one before, will first identify the location of separate infrastructure components, such as 
ski centers, ski trails, etc: and then cartographically overlap these areas to establish the location of a crosscountry ski infrastructure zone.

\subsection{Vermont Cross-Country Ski Trails}

The Vexmont State Comprehensive Outdoor Recreation Plan, known by its acronym as SCORP (1978: VI-7)' estimated that there were 947 miles of established ski touring trails in vermont. The cumulative trail imileage claims of the 41 listed ski touring centers in the Vermont Cross Country Ski Atlas (Bushey, 1983) is 1018 miles. It is the author's own conservative estimate, based on field observation, and cross-country ski guidebook descriptions of non ski center trails, that for every mile of ski touring center ski trail, would be a matching mile of ski trail available. These trails may follow unplowed town, state and forest service roads, circulate around golf courses, or follow summer walking paths or hiking trails. These "uncounted" trails are used largely by local skiers, who might often be the only people familiar with the local trails. With phis estimate, vermont then would have a total of over 2000 miles of cross-country ski trails, a substantial amount for a state with such a small area. It is difficult and not particularly gainful to esti- mate accurately the total mileage of all Vermont ski trails. Defining where skiing activity occurs and the 
existing location of devéloped ski trall networks and facllities in Vermont is considerably more useful. There are numerous ski trail guidebooks available, which assist in locating existing ski trails, in addition to ski trail maps that can be obtained free or purchased at every ski touring center.

As related in Chapter III, 668 of ski centẹs listed in the vermont cross Country Ski Atlas are located in the Green Mountain physiographic region. Examination of the "Ski Touring Centers" in Figure VI (Bushey, 1983: 13), reveals that there are 8 regions" in the state where trail networks interconnect between local ski areas. Six of these areas: otherwise known as cooperative trail networks, are located in the Green Mountain region. At each one it is possible to travel long distances if one knows the local trails, and in most cases the travel is oriented along a north-south axis because the trails tend to run along the slopes of the Green' Mountains.

17 "Choosing vermont for the skiing is a bit like choosing Iondon for the theater - its a great idea, but exactly where do you start?" In order to answer that question, Sally and Daniel Ford selected 25 ski Tours in the Green Mountains (Ford and Ford, 1978: 9):- Their collection is self styled as "A Guide to Vermont's Backcountry Trails". Their work has two implications in relation to the Catamount Trail. The first is that 19 of their 25 ski tours are located within the shaded area of Figure. $V$. The map 


\section{Vermont Ski Touring Centers}

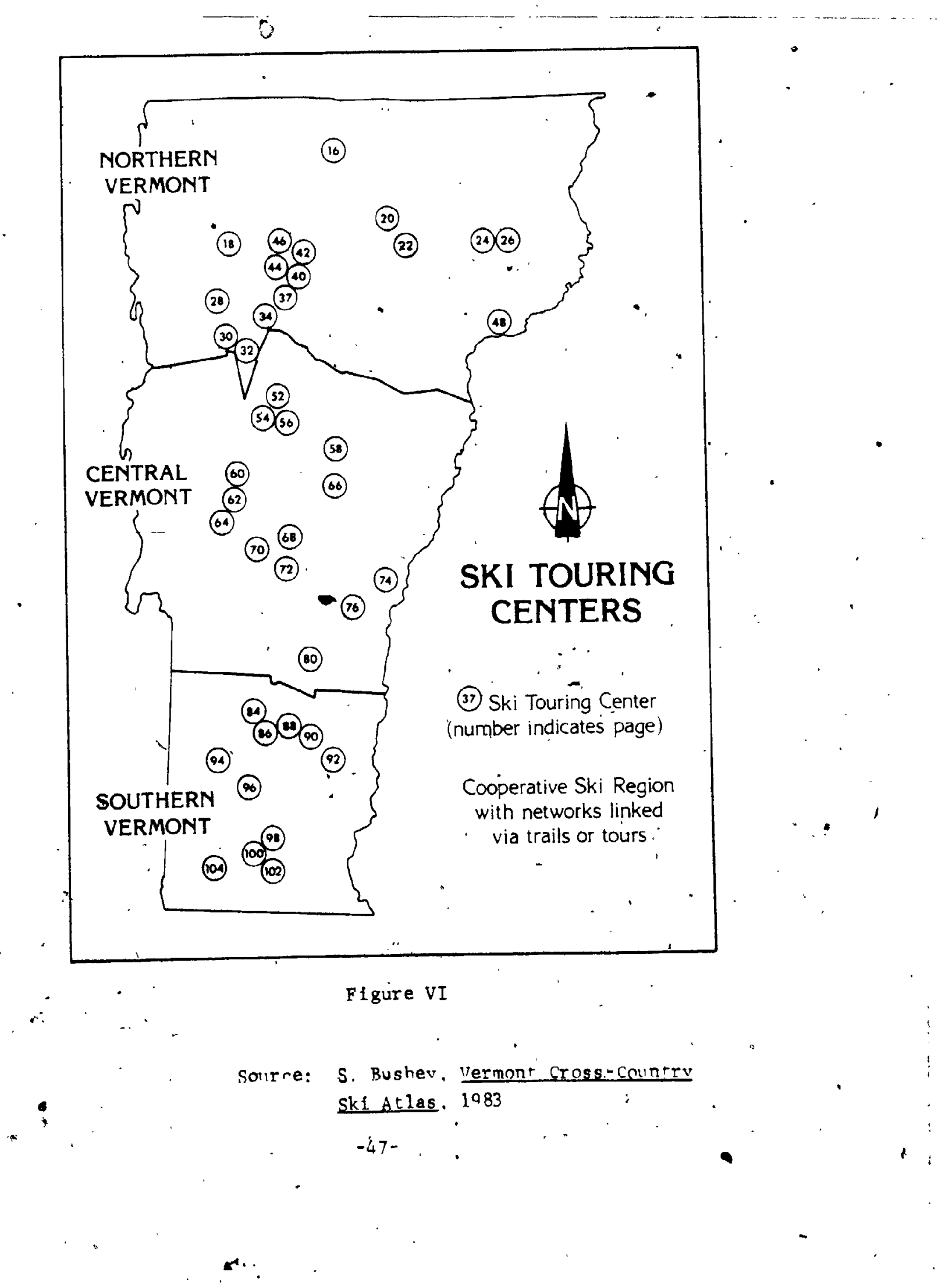


in Figure VII extracted from the 25 Ski Tours in the Green Mountains, illustrates the location of their tours on a somewhat generalized cartographic rendition of vermont.

The second point, is that their tours use "backcountry" ski trails, most of which are not affiliated with existing ski touring centers. These trails are located between the cooperative ski networks and could serve to connect together the established ski trail networks into a longer length route.

In this chapter, both Ford and Ford (1978) and Bushey (1983) have cartographically noted an ample number of trail networks (cooperative) and "backcountry" cross-country ski trails, many of which are located in "Vermont's optimal environmental ski zone" and most are located in the Green Mountains. Other authors such as Tapley (1976), Ziegler (1979) and Allaben (1982 and 1983) have written comprehensive ski trail guides, where many of their trails reviewed are located in the Green Mountains.

Many of Vermont's cross-country ski trails have been maintained, if not constructed by cross-country ski centers. Vermont ski centers are private sector recreation developments. Ski centers have risen to the forefront in creating and promoting cross-country ski trails, services and activities. The services and trails ski centers provide are seen as a necessary component of an "end to end" cross-country. ski trail. 
25 SII TOURS. IN THE GREEN MOUNTAINS

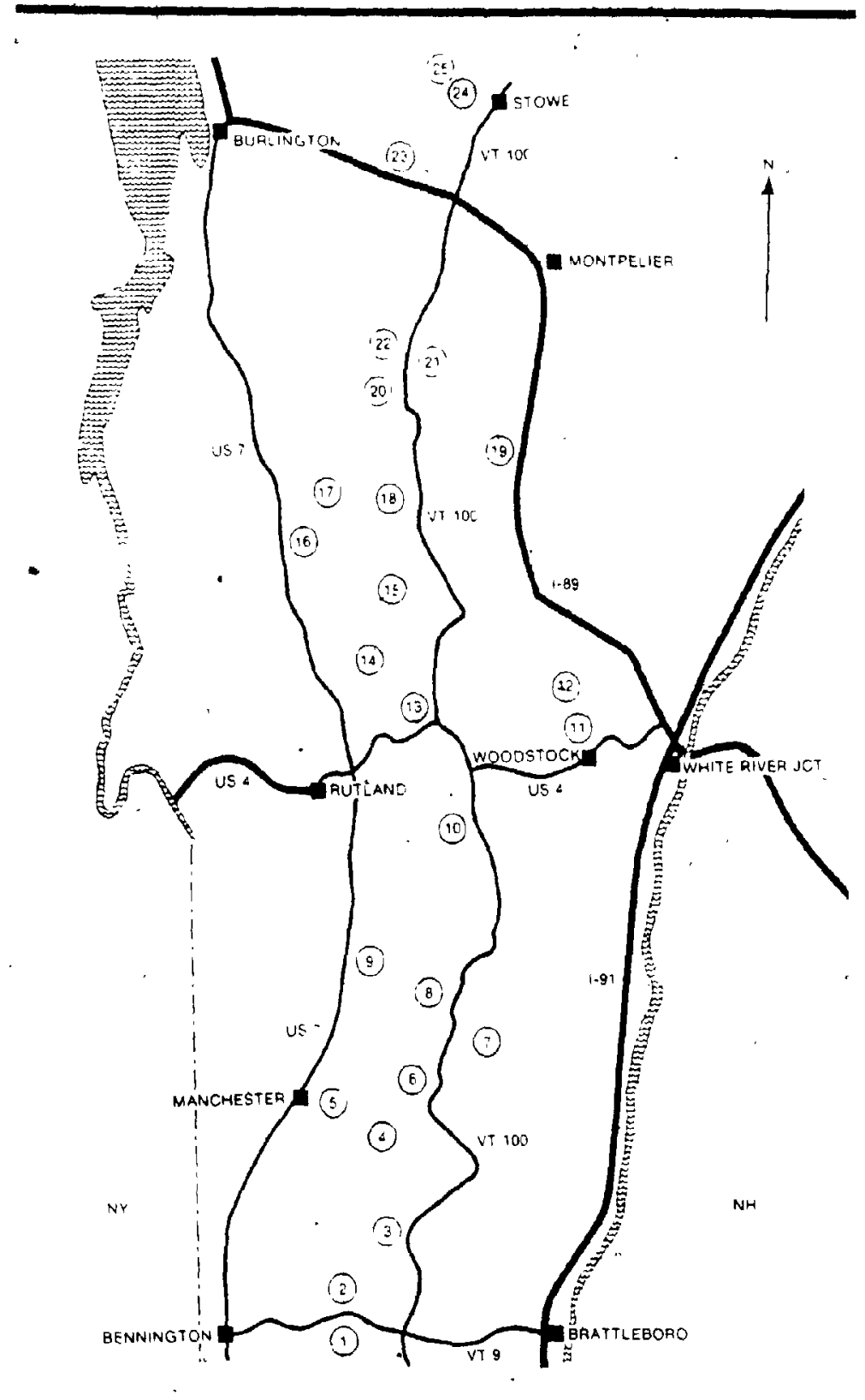

E1gure VII

Sourre: Ford and Ford, 25 Ski Tours In The Green Mointains, 1978 


\subsection{Vermont Cross-Country Ski Touring Centers}

The location of 'the majority of Vermont's ski touring centers (Figure VI), their trail networks and assorted backcountry ski trails (Figure VII) have been identified as located largely within the Green Mountain region and the optimum environmental ski zone. This section considers tit. services skiers require and those customarily available at ski centers within the Green Mountains and tne optimal Environmental ski zone.

The services and facilities of most ski touring centers are usually more extensive than simply the provision of a skiable trail network. Cross-country ski centers, with their trails, services and facilities could serve as central nodes of skier and vacátion activity, for an "end to end" ski trail, where they are located in the optimal

'ski zone: Almost aḷ 'ski centers provide services and facilities such as:

1) tracked and groomed ski trails

2) a heated ski lodge

3) parking

4) ski rentals and instruction

5) dining

6) 21 of the Green Mountains 27 ski centers provide overnight lodging.

An example of a "representative" ski center might be Tucker Hill Ski Touring Center located near Waitsfield, 
Vermont (see Figure VI, $\# 52$ ). Tucker H112, in addition to providing the listed services is like many other vermont ski areas, a year round lodge or country inn. Thus the $\infty$ quality of the hospitality services may often eclipse those of the ski area. The Tycker Hill trail network is extensive and well groomed; it is shared and linked with the trall networks of two other ski centers, Mad River Barn and Sugarbush (see Figure XII), in addition to several other country inns. Cuisine and cooking are emphasized at . many country inn/ski centers. Squier describes the food at Tucker Hill as:

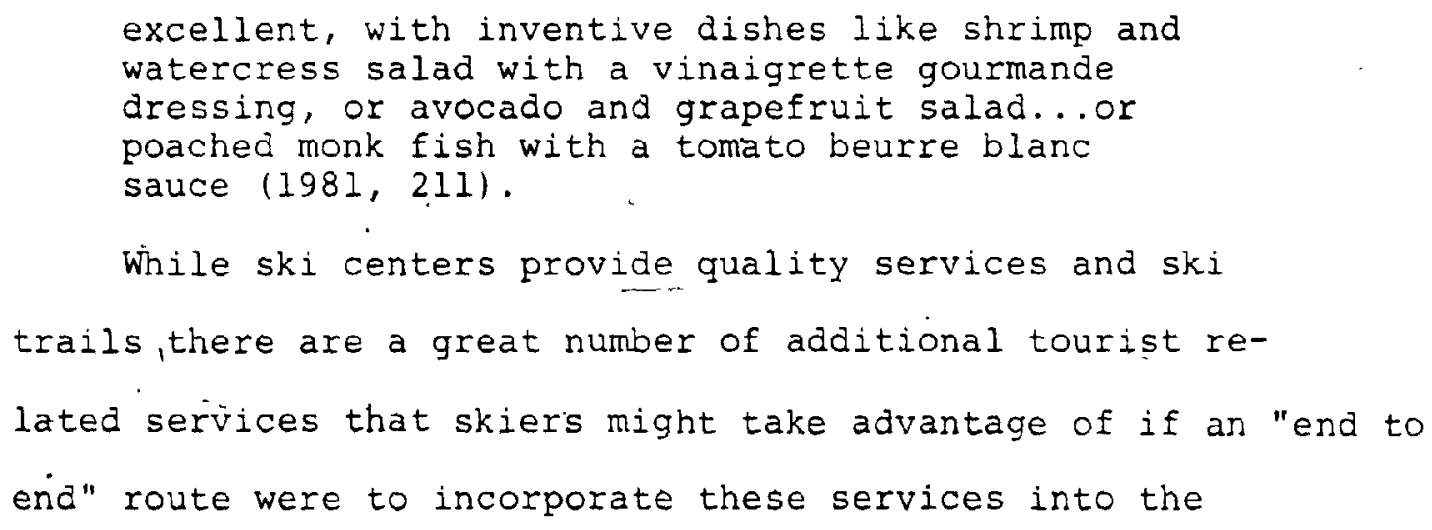

\subsection{Other Related Tourist Services}

- On the map (Figure VIII), Tourist Related Services

Registered with the Vermont Travel Information Council 1974

(Meeks, $1975 ; 935^{\circ}$ it can be seen that tourist related services have a tendency to cluster in both linear and nodal fashion. The area enclosed within the dashed lines, 


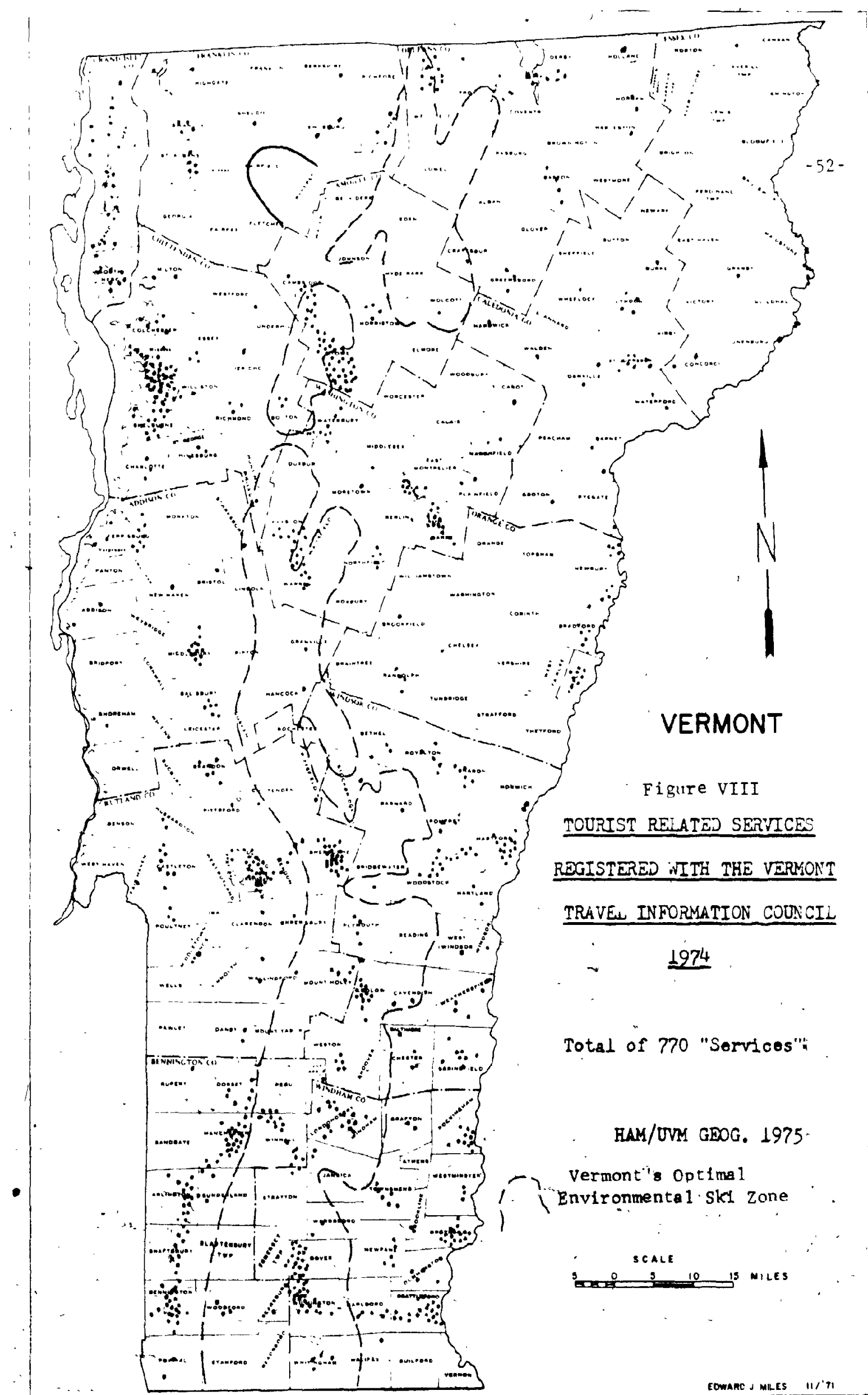

Sour e: H.A Meeks, The rengraphic Reginns of Vermont, 1975 
stretching from Canada to'Massachusetts represents the general location of the designated Optimal Environmental Ski zone. Within this zone there are a large number of tourist services, including many inns, lodges, restaurants, etc., some of which are grouped together and others which are isolated from any other services.

This distribution suggests that in areas where ski touring centers are absent, there are clusters of tourist services, country inns and lodges, that as of yet have no publicized cross-country ski trails leading to or from their establishment. While most regions in the Green Mountains are well serviced by ski.centers and their trail networks, there are gaps (that do occur). In regions where there are nQ ski centers, overnight lodging and services may still be available. With the combined abundance of ski centers lodges and inns, it should be possible to construct a "string" of overnight lodging sites from Massachusetts to Canada, which are no more than a'day's ski apart (15 miles) from "each other and which might adequateIy service or develop services to suit ski tourist preferences.

. The major constraint that may determine the viability of linking certain isolated lodges, ski centers and trail sections together into a continuous trail, may)be the often troublesome task of obtaining landowner permission to extend old trails or develop new ones over public, corporate. and private property. 
Land ownership becomes a critical issue when land is sought for the development of public cross-country ski trails. Land availability is a function of an owner's willingness to allow development. Different landowners often have different requirements that they wish to have satisfied before they willingly grant permission for others to use their land, if they do grant permission.

In the ca'se of Vermont's Green Mountain region there are three general groups of landowners who must be approached for permission to develop new ski trails, which are needed to "bridge the gaps" between existing routes in order to form a continuous ski trail. These landowners can be classified into the following categories:

1) Public land including state and national forest, municipal land and conservation sites.

2) Corporate land including holdings by utility companies, paper corporations and privately sponsored recreation areas.

3) Private landholdings, commercial and non-commercial in nature.

In Vermont, public land, especially in the form of state and federal land, comprises a considerable area in the central and southern section of the state, as displayed in Figure IX Land in Federal and State Ownership (Meeks, 1975: 123). The dashed lines indicate the

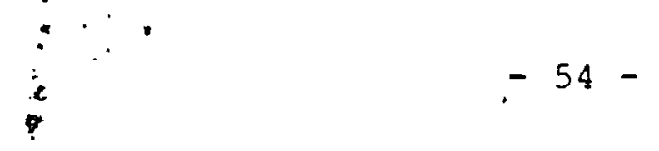




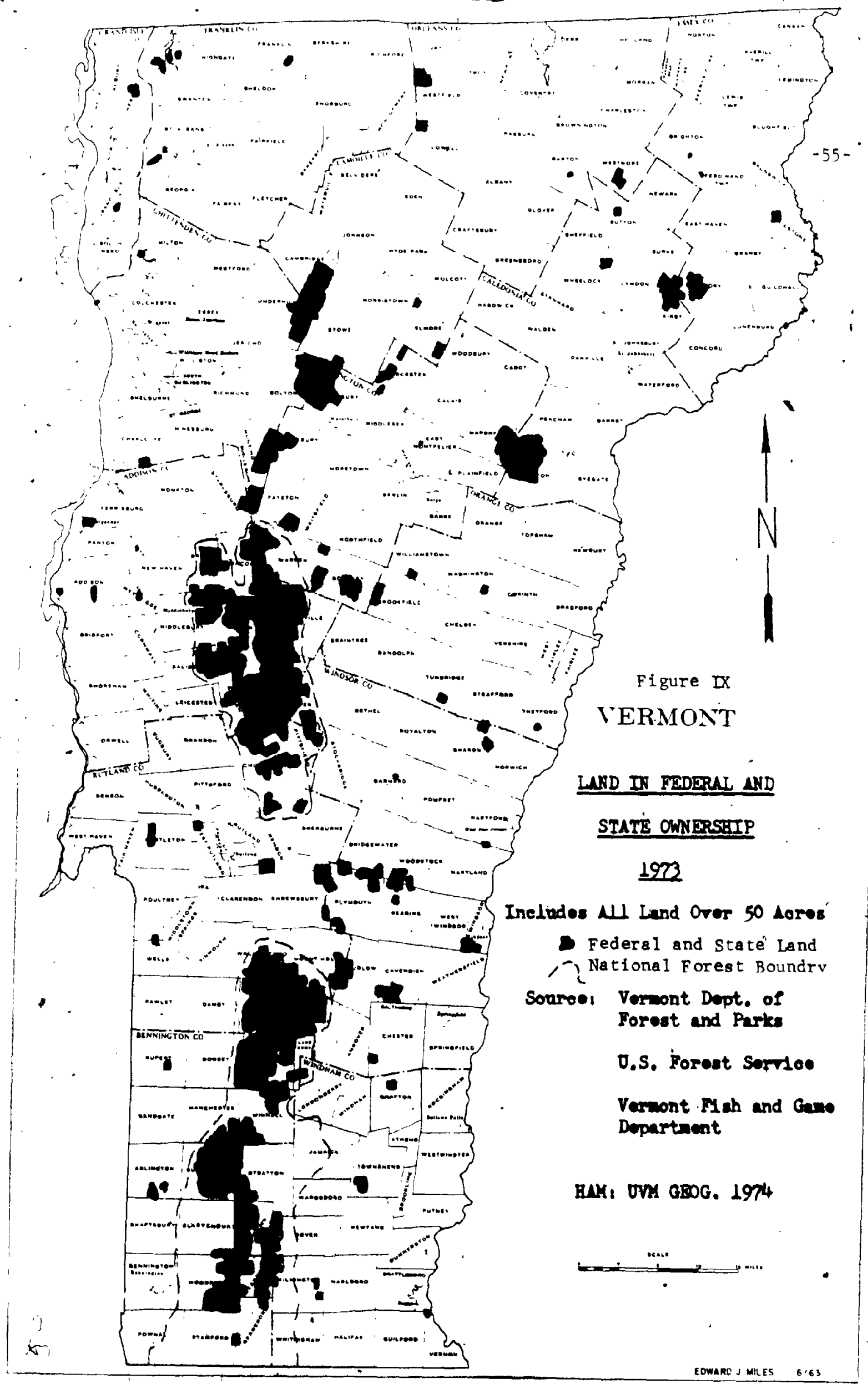


boundaries of land enclosed by the Green Mountain National Forest, while lands north of the national forest are owned by the state forest agency. National and state forest are currently home to many alpine and nordic ski establishments, in addition to many public access winter recreation. trails. They are thus known for their fine recreation opportunities. SCORP (1978) calculated that "approximately 732 square miles, or 88 of the state's land is in Federal, State or Municipal ownership".

The attitude of National state Forest managers toward cross-country trail development on and use of public land for skiing has been móst favorable. The Hermitage; Nordic Inn, Wild Wings, Blueberry Hill and Mountain Top are some of Vermont's ski touring centers that have, in cooperation with the National Forest Service, developed many of their area's trails on public land. Camel's Hump, Mountain Meadows and Mount Mansfield are ski touring centers with trails located on State Forest lagnd.

Because of this attitude, Stanton Allaben's article states that "Public Lands Provide Unlimited Potential for Ski Trails" if skiers collectively approach the forest service with ski trail development proposals. Trail creation on National Forest lands is a matter of being able to satisfy an established trail criterion designed to ensure the creation of a well built, safe, cross-country ski route; (Allaben Nordic Skiing, Oct., 1976: 14). The oppoftunity for public land use lies in the ability of citizen groups being 
able to ensure that a ski trail is properly developed and $\sim$

maintained and that it meets forest service standards.

Examples of major landholding corporations include utllity companies, paper corporations and resort developments, such as alpine ski areas. The sizes and locations of corporate land holdings in the, Green Mountains a relatively unknown. From the author's personal observations, it is known that corporate interests such as utility companies and pulp and paper companies control many large land parcels In the Green Mountains, more so in the northern part of Vermont than in the central and southern state sections. Corporate land holders in vermont have in the past been most cooperative in allowing and facilitating recreational use of their properties. One such example of corporate cooperation is the Atlas valley shelter south of Jay Peak on The Long Trail.

This small leanto of plywood and plywood cores has been provided for the use of hikers and picnickers by the Atlas Plywood Division, over whose timberlands this portion of the Trail passes (Green Mountain Club, 1971, 139).

One incentive for corporations to allow public use of their land is the dividends it pays in creating a more positive public image. Recreational use of such land rarely con$\lambda$ flicts with business operations. Meeks, discussing the problem of accessibility to non-public lands, says that

- "large paper company ownerships in the northeastern portion of the state (St. Regis, Atlas Pl ywood, Brown Brothers) probably assure public access to that area" (1975: 119): 
Access to private land in Vermont, for public recreation use, is a growing problem. Meeks states that the amount of posted land is "very rapidly increasing".

It would be the author's estimate... that nearly a third of all privately owned land in the state shows "ho trespassing signs. With Vermont's some 9300 square miles of land area, there is probably something like 2600 square miles of privately owned land posted (1975: , 119).

Attempts to develop ski trails over private land would seem undesirable, if circumstances permit options of ac quiring new ski trail links over public or corporate land: The later options should be considered and preferred since even when trails can be developed over private land, 'with landowner's consent, there is always the possibility that in the "future the landowner may change his mind or sell his land to someone less generous. It may take onily one landowner closing his land to temporarily or permanently dist rupt the passage of skiers using a point to point rail.

While public land would seem preferable to private, significant winter trail systems have been built over pri-) vate land, especialiy snowmobile trails. The vermont Ass

ciation of Snow Travelers or VAST (1981: 24); believes Vermont Public Law 31 Vermont Statutes Annotated (V.S.A.) 806, passed in 1971, assisted greatly in helping build a. state wide trail network." The law states:

No landowner shall be liable for any property " damage or personal injury sustained by any per-. . son operating or riding as a passenger on a snowmobile or upon a vehicle or, other device drawn by a snowmobile upon the landowner's property, whether or not the landowner has 
given his permission to use his land unless the landowner charges a cash fee to the operator or owner for use of the property.

While 31 V.S.A. 806 clearly absolves a landowner from liability regarding snowmobile use of his land, it does not make any similar provision that would benefit cross-country skiers.

For the Catamount Trail to become a reality, new ski trails must be built over public:, private and corporate land to link the existing systems into a complete route. Obviously, the eventual route should be located where the availability of land, is most assured. National and state forest agencies administer and own hundreds of square miles of land in the southern and cehtral Greeh Mountains that should provide fine trail development opportunities. Corporate lands provide more limited opportunities, but private lands are seen as least desirable because of posting trends, even though there are major snowmobile trail systems built over private lands in Vermont. Public larids should be the focus of any new additional trail, development because of their ease of access and locational advantages, being concentrated in the designated optimal environmental ski zone.

\section{4:6 Green Mountain Cross-Country Ski Infrastructure Zone}

The method used for identifying vermont's optimal Environpental ski zone (Figure $\nabla$ ) ean also be used for " 
identifying' the location of a Green Mountain ski infrastructure zone. Figures VI, VII, VIII and IX respectively indicate the position of vermont ski touring centers, ski tours and trails, tourist related services and land in Federal and State ownership. By overlapping and plotting these areas on a single map, the infrastructure zone clearly emerges. The Green Mountain Cross-Country Ski Infrastructure Zone. (Figure X) runs from Massachusetts to Canada, with an interruption in Northern vermont where there is a noticeable lack of skiing infrastructure. Within the in-. fracture zone itself the most suitable regions for the development are those areas where factors such as public land, ski centers, trail networks and tourist related services overlay and are available.

The introduction of the next' chapter carries this overlay process a final step further. By overlapping Vermont's Optimal Environmental Ski Zone and the Green Mountain Cross-Country Ski Infrastructure zone it will be possible to identify a zone of highest potential for the routing of an "end to end" ski trail. 


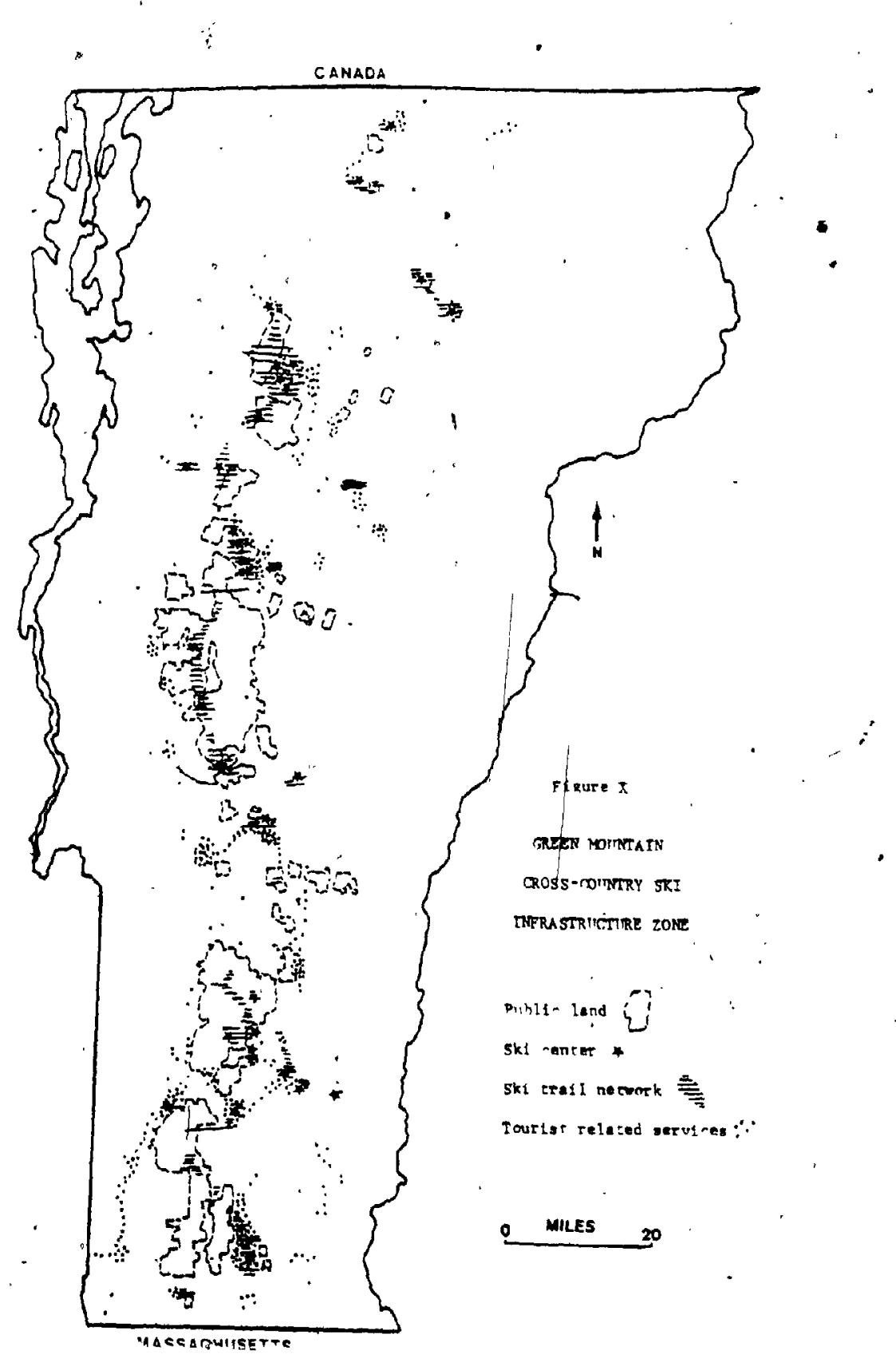

Source: complled from Figure VI, VII, VIII and IX.

$-61-$ 


\subsection{Analysis and Tentative Route Selection}

1

Ploting Figure $\mathrm{x}$ the Green Mountain Cross-Country Ski Infrastructure Zone, over Figure V, Vermont's Optimal Environmental Ski zone produces a third larger region (Figure XI) that has characteristics of each zone. The overlapping area of the two zones would theoretically contain the most favorable territory for cross-country skiing since it has both optimal environmental assets and a well developed ski infrastructure. The qualities of these two combined regions and especially their zone of convergence might be described as follows.

1) Many areas with an annual snowfall of " 80 " or more a year.

2) Low mid winter temperatures, that reduce frequency of thaws and othen generate higher snowfalls.

3) a landscape of many highlahds and mountains, with substantial areas of land above 1000' elevation.

4) the two zones contain more than two-thirds of vermont's cross-country ski areas.

5) within the zones a large number of backcountry ski. trails and ski networks exist, that connect together winter lodges, other ski trails and ski- centers.

6) the combined regions have many tourist related services that skiers might use.

7) within the two zones are substantial public land holdings, which would be accessible for tratl development." 


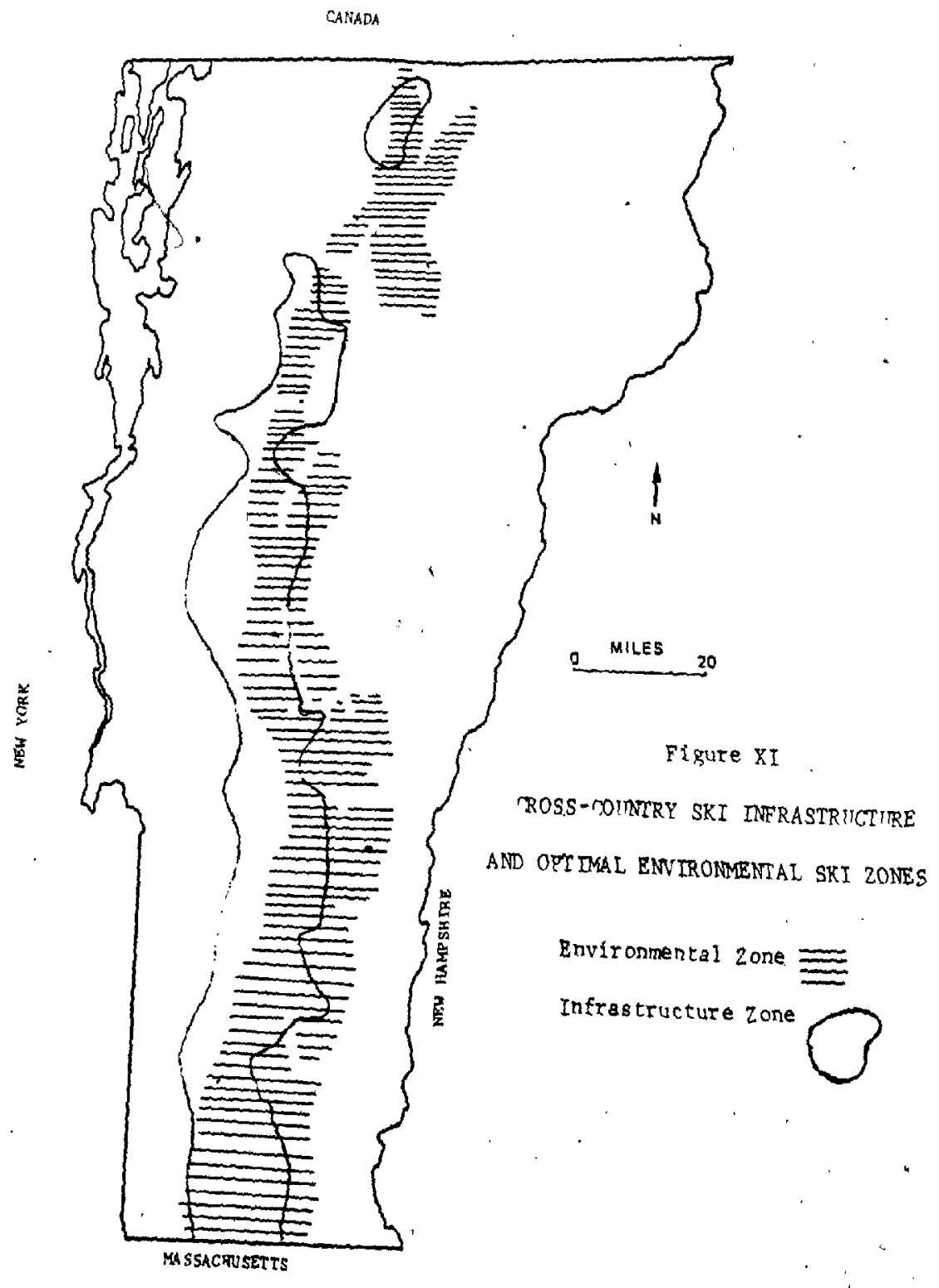

$-63-$ 
Within the Cross-Country Infrastructure zone and the Optimal Environmental Ski zone but especially their area of overlap lies great potential for creating an "end to end" ski trail. The next stage of this research employs a mapping methodology or route selection analysis which will determine an optimal ski pathway for the "end to end" trail which can be tested at a further stage of inquiry.

\subsection{Mapping Methodology Used for Route Formation}

In the preceding section, Figure XI had identified the regions demonstrating the greatest overall potential for location of an "end to end" ski route, more detailed research was aimed at identifying specifically, which ski trails, lodges and ski touring center nodes could be selected and linked.in an overall state-length. ski trail plan within the optimal natural environment ski zone. In the following methodology all decisions related to the selection of trails or service sites were guided by the route selection design criteria, outlined in Chapter II and . briefly restated here. The design considerations that have affected the placement of the Catamount Trail are related to the following criteria:

1) skier safety

2) length of the local ski season as determined by climatic indicators such as snowfall and mean temperature 3) an expected moderate or better trail use volume 
4) trailside availability of skier services and facilities

5) an average to moderate trail difficulty

6) preference, for trail routing through public land

7) a minimum expense trail development by using existing facilities and ski trails

8) avoiding as much as possible trail use conflicts with

- other winter recreationists

A simple cartographic methodology was used to designate the location of an "end to end" ski trail route. The process was multi-stage where informatign was progressively collected, cartographically plotted, jhalyzed and refined. The initial maps used in this investigation were small scale $(1: 316,000)$, which suited the amount of information initially available. By the end of the process the amount of information had multiplied and grown in precision, allowing the information to he laid out on larger scale maps $(1: 62,500$ and $1: 24,000)$, which led to the trail draft. The methodology involved the following stages.

Stage 1 consists of collecting ski trail information and transcribing the relevant data onto the Vermont 1982-83 Official State Map (Vermont Agency of Transportation and Vermont Agency of Development and Community Affairs, 1982). The initial data entries were limited, so the map's small scale $(1: 316,800)$ suited the amount of information that needed to be plotted. Commercial publications and brochures, in addition to state hospitality and skiing guides were purchased or had already been collected or solicited 
through mailings to form a general bank of information. Ski touring centers, inns, lodges, ski trails, wilderness ski trails, unplowed roads, etc., located within or close to the area of study were plotted on the small scale state map with identifying symbols.

Stage 2 involved assessing and identifying emerging patterns from stage 1. It became apparent that there were localized concentrations of ski touring centers, inns, lodges and ski trails and routes. Once plotted on a map, these concentrations of trails and service centers were seen to be oriented along a north-south axis, as a rule contained in valleys, sheltered by north-south trending mountain ranges and ridges, from excessive wind and sun exposure.

Stage 3 involved more detailed research on areas with concentrations of ski services. This stage coincided with the author's employment (summer 1983) as editor and compiler of Northern Cartographic's Vermont Cross Country Ski Atlas. The consequences of this employment in relation to this thesis were two fold. First, in travel to different ski areas around Vermont, the author was able to collect over 40 very detailed cross-country ski maps for each ski touring center. Secondly, the author had the opportunity to meet and discuss with ski area operators the concept of an "end to end" Vermont ski route. Their knowledge of the immediate area and suggestions on "how to get from here to " there" were most helpful. Many of these ski area operatoro * 
were helpful to the extent of drawing recommended routes for skiing on topographic maps.

Two such examples of ski center trail maps (Figure XII and Figure XIII) are presented on the following pages.

These two maps portray the separate but interconnecting ski touring centers of Sugarbush, Tucker Hill and Mad River Glen, which are located next to the towns of waitsfield and Warren, in central Vermont.

Stage 4 involved compiling and plotting the research data gained from the collection of relevant cross-country ski center maps onto U.S.G.S. topographic maps at the scale of 1:24,000 and 1:62,500. This step might be considered a final resource inventory of all trails, inns and ski centers in the Green Mountains. This step allowed an accurate assessment of the relative length of the ski trails and the degree to which trails efnnect or come close to connecting. The topographic map on Figure XIV, has been created by splicing together two sections of U.S.G.S. quadrangles $(1: 24,000)$ Mt. Ellen, Vermont and Waitsfield, Vermont.

This map covers the overlapping terrain between Sugarbush Ski Touring Center and Mad River Glen Nordic Center. During stage 4 , the principal trails connecting the ski centers were sketched onto topographic working maps, as has been done here. This editing process enabled the author to eliminate any extraneous information that was irrelevant to the project.

Stage 5 was essentially to plot a tentative "end to end" 


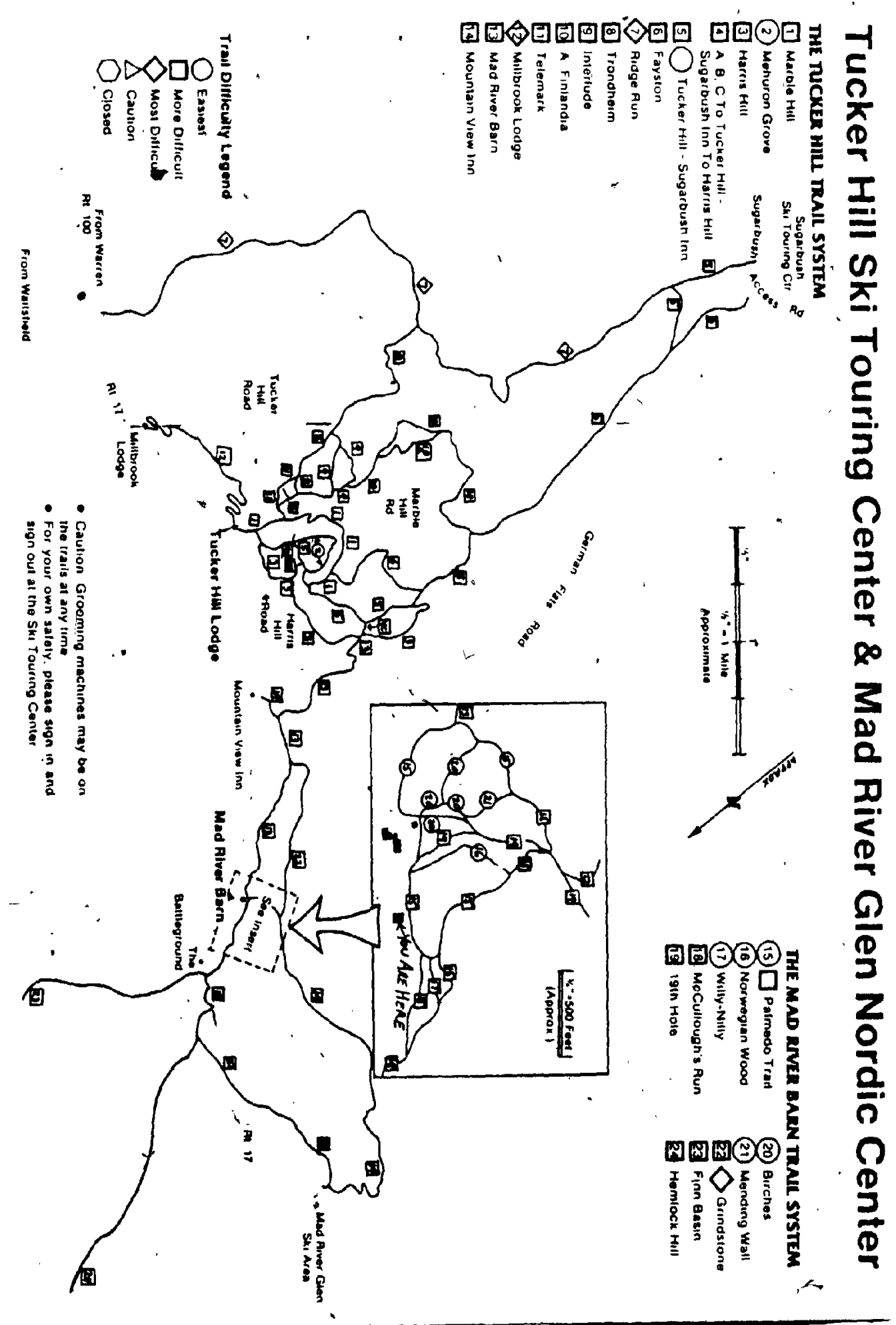

Source: Tucker Hill ski Touring -enrer. 1983 


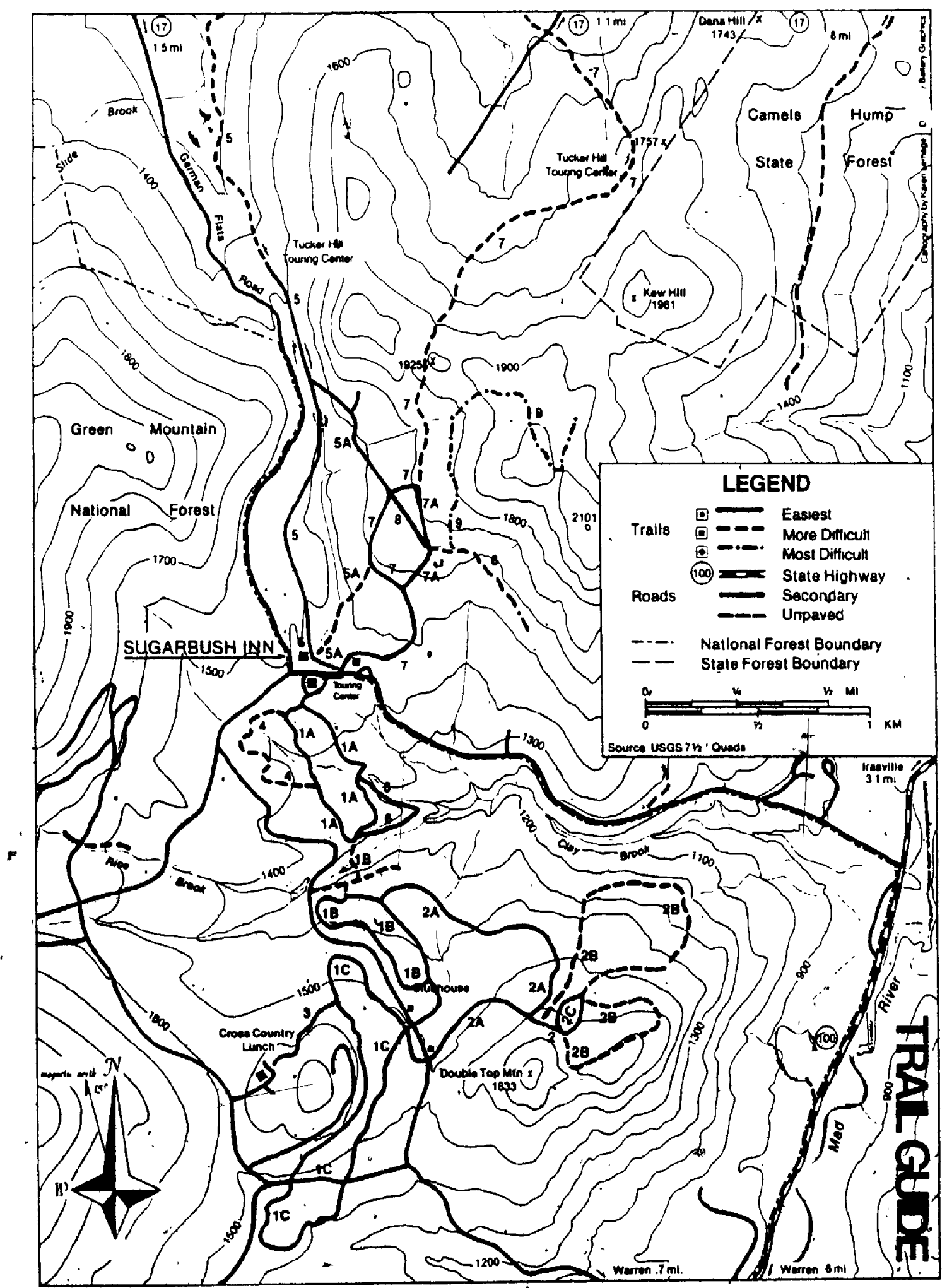

Sarte: sugarbuth sk1 rouring center, 1083 
Figure XIV

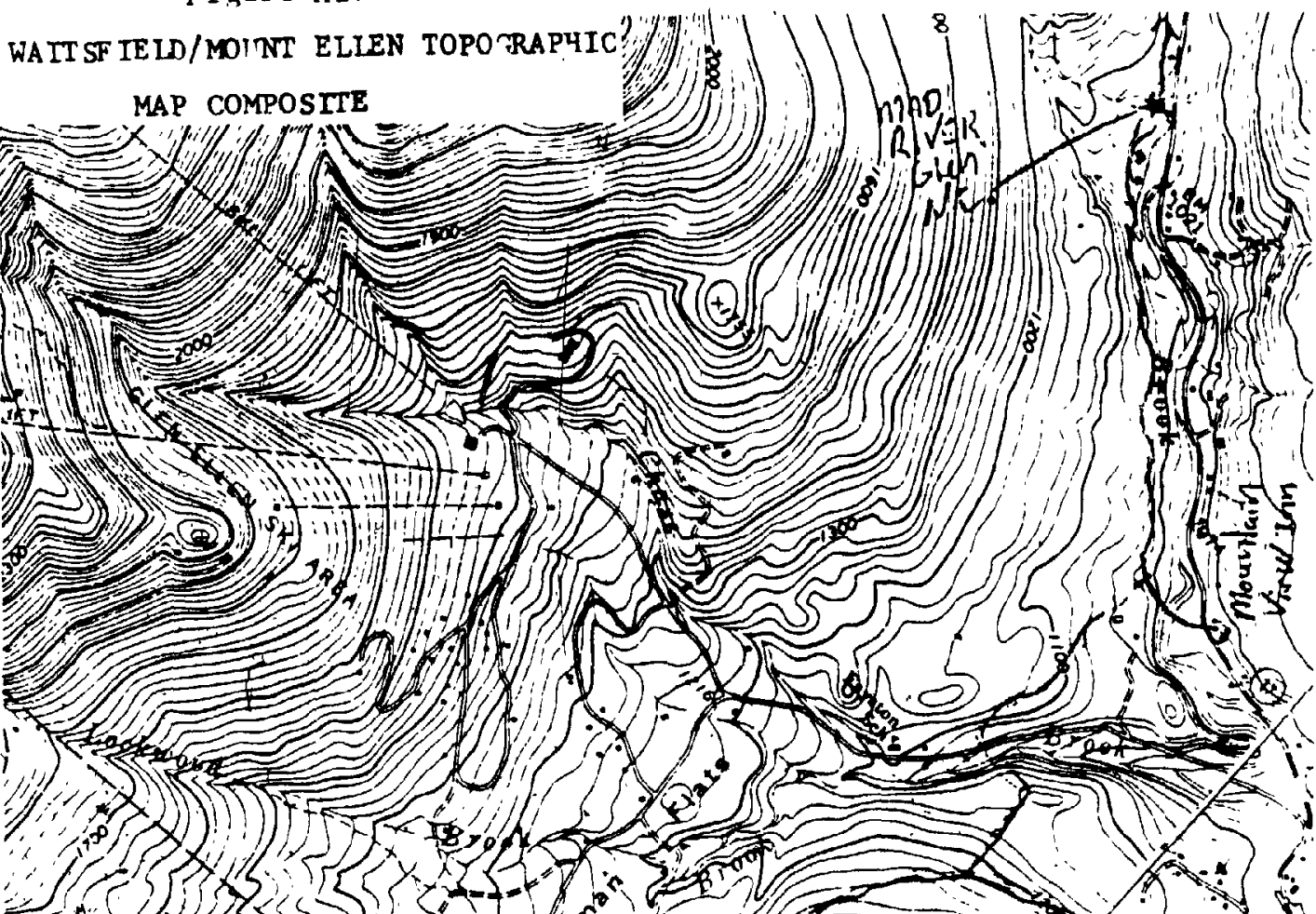
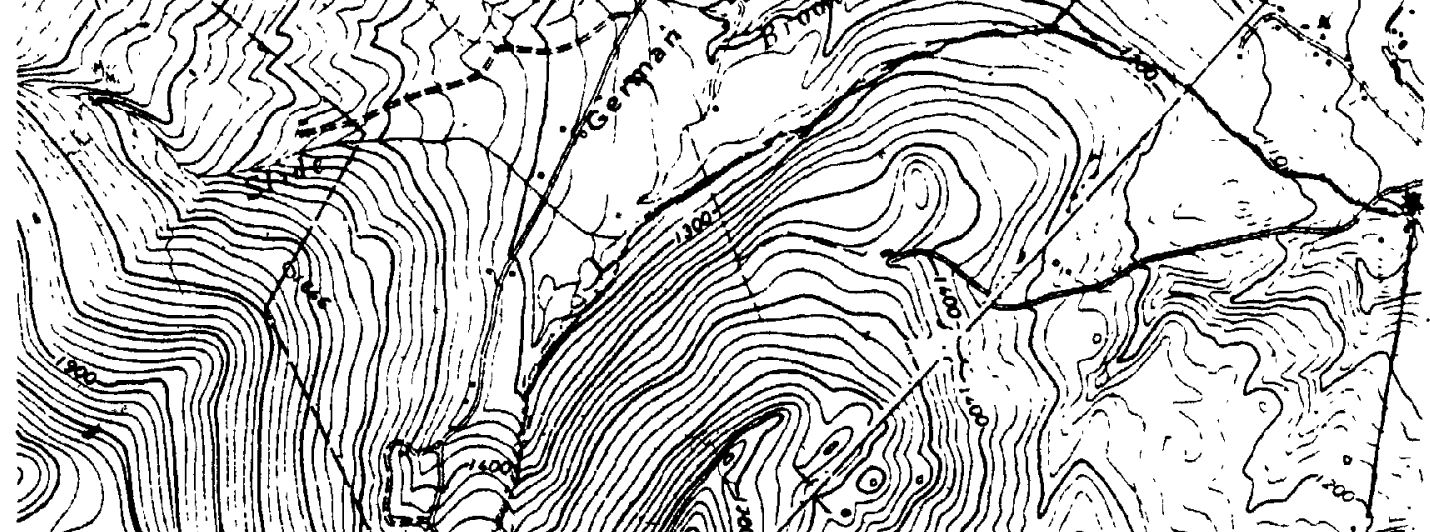
ski route with the available information. This meant identifying skiable north-solth trending trail segments and the "trailess gaps"'between these skiable segments. Potential ski linkages for the "trailess gaps" were formulated and plotted for later field testing.

Stage 6 consisted of compiling this cartographictlly represented "end to end" route information into a written ski trail guide or summary. This guide described the trails, lodges and ski centers along the proposed ski pathway. Points or sites of note were assigned a mileage index number, designating their relative distance from the southern most point, the Massachusetts border (mile 0.0 ) to the terminus at the Canadian border, (mile 260.0). Stage 7 The final stage involy the field "testing" in March, 1984 of: the proposed Catamount Trail, which consisted of a three week ski trip over the designated pathway to determine the overall feasibility. This field investigation is described in the following section.

\subsection{Ski Trip Planning}

The best way of reviewing the proposed route and thus the entire proposal of creating an "end to end" ski route in Vermont, was to ski the pathway designated in the preliminary "traif guide". Skiing the proposed route, would. provide the first hand opportunity of observing and evaluating ski trails and skier services available; it would 
test the feasibility of the trail proposal and reveal sections of the route where improvements might be made to increase local skiability, eliminate hazards and particularly difficult stretches.

The author is àn experienced skier, with a cross-, country skiing background (of mofe than 15 years) -accumu- . lated on trails in the states of Maine, New Hampshire, Vermont and the province of Quebec.' The proposed route, because of its $260 \mathrm{mile}$ length, a projected three week time commitment, logistical complexities and potential severe. and hazardous winter weather conditions, could not be skied as a solo effort. Therefore, two companions (Ben -Rose of Burlington, Vermont and Paul Jarris of Podunk, North Caro- Iina) were recruited months before the actual departure. date, to ski. the proposed route with the author. Both-Rose and Jarris, are highiy, qualified cross-country skiers, 'who had in the past accompanied the author as team members on lengthy winter trips and ski excursions.

The intended method of skiing thatamount Trail was to ski every day, from "inn to inn" or "lodge to lodge". The group planned average daily runs of 12 to 20 miles,: which would be for most experienced skiers a comfortable distance to ski in a day. The exact distance of course was determined by the spacing of accommodations along, any, given section of the route. During January accommodations were. selected and arranged throughout the length of, the cata- : mount Trail, and by late February, all final details had 
been arranged for the final stage of investigation, the March testitrip.

\subsection{The March Test Trip}

\section{\&}<smiles>CCC</smiles>

The purpose of the March, and the skiers test trip, was to have a first hand chance to evaluate the feasibility of the proposed route. It afforded the author an opportunity to identify unsuitable sections of the pathway and if necessary to select better routes that more fully satisfy the initial trail selection criteria.

The trip itself lasted the first three weeks of March, the skiers skied, an estimated '270 miles from Massachusetts to Canada. A láte February thaw lasting two weeks, while not a problem on the March test trip, threatened to cancel the venture before it started. The thaw helped - identify those areas in the state that, are most susceptible to early snow cover loss. Snow cover retreat patterns, during the thaw, strongly suggested that Vermont's optimal environmental ski zone, is in reality the eastern portion of the Green Mountains. The anly cross-country ski centers that avolded ćlosing during this thaw in the state were in. the Green Mountains.

The problems encountẹred during the Makch trip must be placed in perspective, for in general there were few

- problems. As evidence of this, the ski expedition group. was able to maintain its daily schedule and arrive, at the

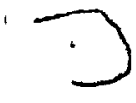


night's lodging before dark on all but two occasions: The' daily ski trails and routes were mostly at novice and intermediate difficulty; there were few difficult sections: With few exceptions, the route's length was covered with a deep snowpack and the skiing conditions were very good, often with new powder snow to glide over. The ski touring center's hospitality and services exceeded high expectations, making the nights as restful and relaxing as the days were active.

Problems which would have an impact on the trail's overall feasibility were confined to a few geographic sections of the route proposal and were related to either and in some cases both, the quality of the physical environment and the regional recreation infrastructure. In some cases, the quality of the physical environment and recreation infrastructure were considefed to be of an inadequate nature, so much so that it would be difficult to satisfy the formulated trail design considerations (criteria). In such . cases it was concluded that a relocation of the regionally proposed section of the Catamount Trail would solve problems related to environment and infrastructure. The occasional physical-environmental problems encoyntered were as follows:

1) Weather conditions were often cold and windy, with one. ice storm.

2) The landscapes lying beneath 1000' elevaition, for reasọns of strong winds, insufficient snowfall and suninelt 
due to slope exposure, had snowdepths and conditions just barely sufficient for cross-country skiing.

3) Thère were certain landscape and terrain conditions that were unsafe for cross-country skiers, such as steep slopes and thin ice over reservoirs.

The major observations and infrequent problems related to the Green Mountain's recreation infrastructure are as * follows:

1) While there are many cross-country ski trails, a small number are poorly marked and maintained. These conditions considerably reduce a trail's value as a winter recreation resource and open the possibility up of a skier getting lost on a listed and publicized ski trail.

2) Vermont ski touring center trails are well maintained and marked. Their skier services of all types such as meals, lodging guide services and instruction are out-: standing.

3) The spacing of ali 'services along the proposed route is very convenient, with there being few areas where one would be Hore than four hours away from the next ski center or service site if a well marked and maintained trail connected such sites.

4) The skier difficulty of most ski trails and proposed linkages might be rated as easy to moderate.

Overall, the problems efcountered during the March test trip were infrequent and confined to a.limited number of regions in Vermont. These problems are not lobstacles 
to creating an "end to end" route and solutions are proposed in the final chapter that resolve any trail complications due to an inadequate cross-country resource base. The next section $(5.4)$, records impréssions of and reviews the characteristics of specific state trail fions. that were skied during this author's March field test. This review identifies those trail segments along the "end to end" route which are rated as highly feasible and those that are in need of revision.

\subsection{Trail Subdivision Sections}

Based on the test trip impressions, and analysis of the route, it is useful to subdivide the trail into dis-. tinct segments, in order to better describe the route and provide a basis for specific planning recommendations. The trail can be subdivided into 14 different sections which rainge in length from 5.1 miles to 34.8 miles. The sections are defined and evaluated based upon considerations, related to the initial trail design criteria. In $f^{\prime}$ general, the sections were named after dominant landscape features, principal skijng centers and in some cases, the same name fitted botti. The characteristics reviewed in each trail section summary are those that have a special bearing, either positive or negative, on each local section's feasibility as a part of the whole "end to end" trail. The brief observations that have been made about i.,$\quad-76=$ 
specific trail sections are related to:

1) skier and ski trail safety

2) physical-environment factors such as snowcover, terrain steepness, elevation, etc.

3) current and potential ski trail use volume

4) availability of skier services and facilities along the route

5) degree of trail difficulty

6) public land availability

7) current level of infrastructure development and coordination between services, facilities and ski trails 8) avoiding use of trails that might cause conflicts with other winter recreationist

The two following sets of maps, which precede the trail descriptions are to be used in conjunction with the section descriptions. Figures XVI and XVIII display important Vermont Highways, Towns and Trails and their locational relationship to the initial route of the Catamount Trail. Figures XV and XVII the Veamont Trail Sections and Nordic Ski Areas, identify the location of 22 ski touring centers along the Catamount Trail.

The following text evaluates the pre-revision ski trail route which, the trail expedition team skied over.

Southern Section, Massachusetts border to The White House Ski Touring Center in Wilmington, 11 miles. The Southern 
F 1 gure $X V$

\section{SOUTHERN VERMONT TRAIL SECTIONS}

AND

NORDIC SRI AREAS

TRATL SECTIONS

A SOUTHERN

B STRATTON-SNOW

C GALE MEADOWS POND

D DEVIL'S DEN

E SHREWSBURY

$F$ THE VALIEY

G MT. MEADOWS-MT. TOP

NORD IC SKI AREAS

$\$ 1$ The White House

2 Sitrmark

3 The Hermitage

4 Stratton

5 Nordic Inn

6 Village Inn

7 Mt. Meadows

8 Mountain Top

$\star$ SKI AREA

$\dot{-}$

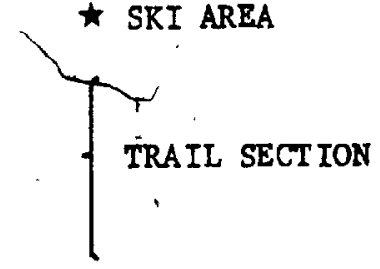




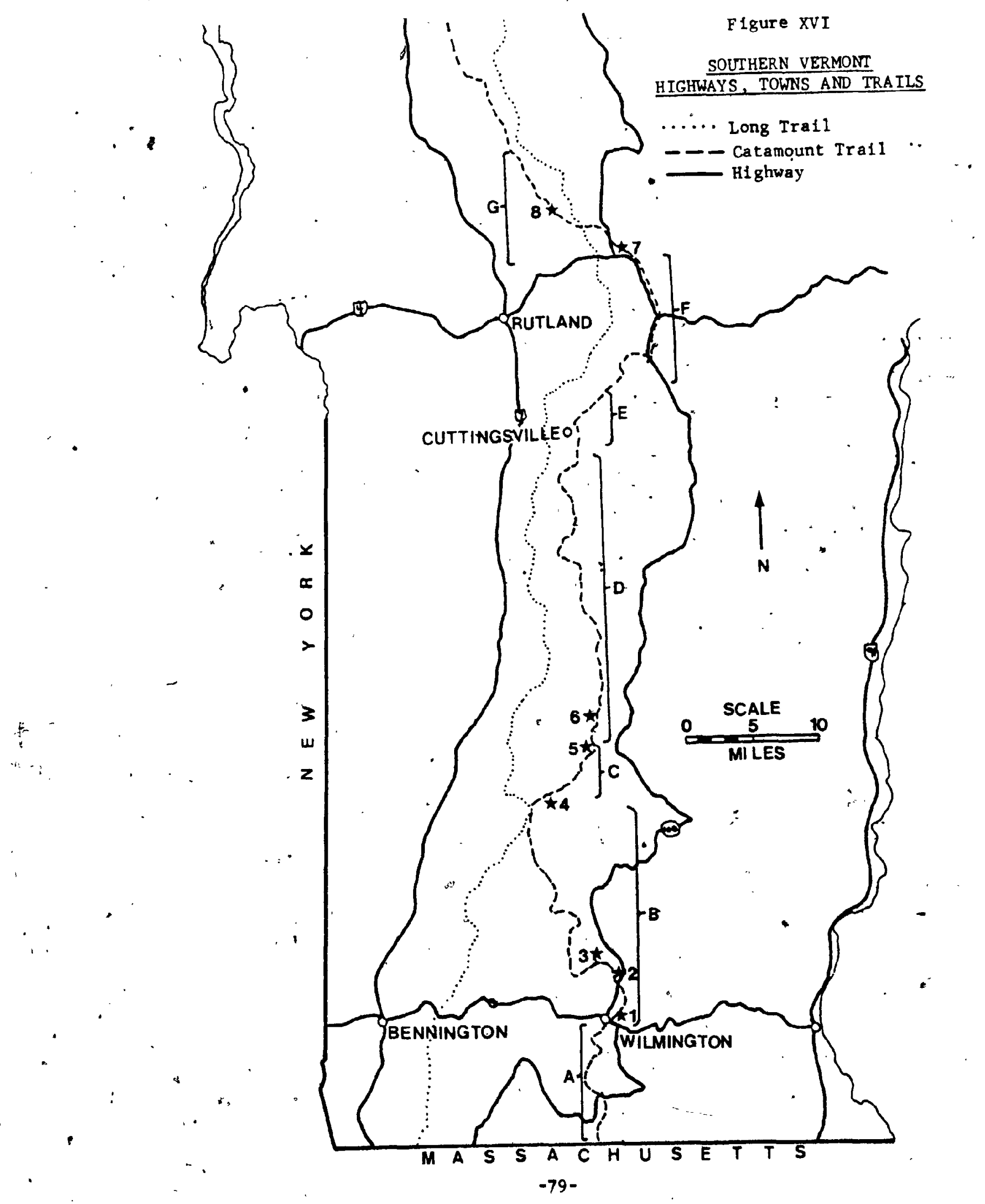




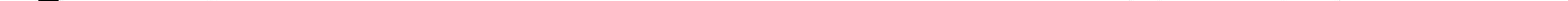




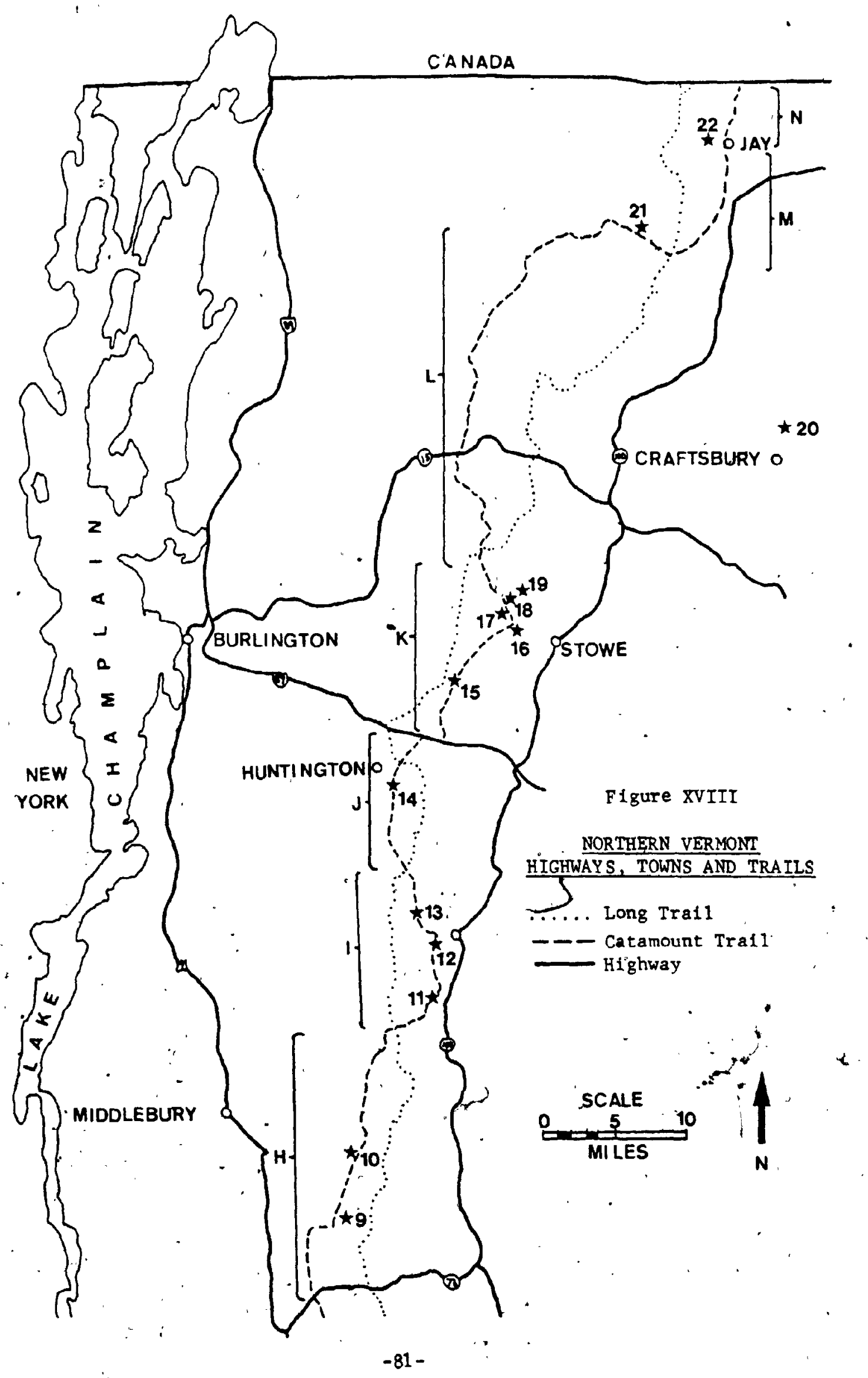


Section is characterized by gentle to moderate, rolling terrain that is easily skied. The proposed routeway is entirely to the east of any public property, specifically the Green Mountain National Forest (GMNF) and thus on private land. The landscape is mixed agriçultural and forest, with elevations higher than 1500', which ensures reliable snowcover. Currently this region has few ski trails. If ski trails were developed in this region they would probably enjoy high popularity due to southermermont's proximity to large urban centers in Massachusetts, New Hampshire and New York.

Mount Snow-Stratton Mountain Section, The White House to Stratton Ski Touring Center, 30.5 miles. This section not only offered the best sking in Southern Vermont but it also displays excellent prospects for development of new ski trails because of its location within the GMNF on public property. Most of the route crosses highlands above 2000', which are quitegentle, suitable ski terrain for all abilities. Four ski touring centers (The White House, Hermitage, the Sitzmark and 'Stratton Mountain), in addition to a public trail system at Grout pond, offer a fine network of nearly connected ski, trails. This region's reputation for deep snows was verified, despite the recent February thaw, as many areas still retained up to two feet or more of old snowpack. The length of the trail passes almost entirely through forest and wilderness. 
Gale Meadows Pond Section' stratton Ski Touring. Center to Nordic Inn, 9.1 miles. Half of this section lies within the boundaries of the GMNF. From the village of Bondville and north (after a long descent from Stratton) the ski route varies little in elevation, holding between $1200^{\prime}$ to $1500^{\prime}$. The landscape is pastoral; many old farms and houses are visible, including a cemetery containing markers dating back to the early 180,0 's. This section of the Catamount Trail is largely undeveloped in terms of ski trails and service's. An exception is the town of Bondville and the nearby, town of Rawsonville, where there are a number of inns and lodges, several ski shops and a few short cross-country ski trails. This section of the proposed route, because of its proximity to so many services; would probably receive a fair amount of use if properly con, structed.

is.

Devil's Den Section, Nordic Inn to Route 140, 19.1 miles. This section is entirely within the GMNF. Other than for several small farm fields in North Landgrove and Wałligford, this area is completely forested. The Village Inn and the Nordic Inn provide ski trails, lodging and other skier services;. The overall skiing difficulty of the region Is slight, since much of the skiing odcurs over forest service roads, which are wide, unplowed and well graded. The high elevations, from 1300' to over:2000', ensure a long ski season. This section currently has trails running 
- its entire length, with the exception of a 5 mile stretch between the Village Inn and the Nordic Inn, where an old overgrown ski trail exists that might be resurrected for future use.

Shrewsbury Section, Route 140 to North Shrewsbury, 6.3 miles. This section of the proposed trail was unskiable during our March test trip and a disappointment. It dips to a low elevation of 1000' in cuttingsville. The terrain was made unskiable by a collection of boulder strewn fields, which because of their southwest facing orientation, gave the sun and prevailing winds an opportunity to melt and blow away much snowfall. Because of the difficult terrain and probably generally poor snowcover, this section is regarded as highly unskiable. Thus consiffration should be given to relocating this section eastward where better conditions might be found for"skiling.

The Valley Sect 7 , North Shrewsbury to Mountain Meadows, 15.8 miles. The Central Vermont Green Mountains near Killington Peak-are high sharp sided peaks, with only one. passage between their summits, that leads in a north-south direction. The only viable ski raite is along the hearly level valley floor that ranges in elevation from $1100^{\prime}$, to 1300', through which highway Route 100 runs. The valley

- is generally wide enough to accept both skiers and road; except for a short section (1/4 mile in length) where even 
the road has to squeeze between the hill sides. While this region lacks nordic ski ceńters it does not lack services. The northern half of this section, near the Killington Alpine area, has a number of lodges, stores and ski shops. There are several old and unplowed roads in the valley that might be easily converted to ski trails and would appear to receive a fair deal of skiing use, being close to a mil traveled highway. The terrain is generally gentle and would be enjoyed by all levels of skiers.

Mountain. Meadows and Mountain Top Section, Mountain, Meadows to Route $73,21.2$ miles. This section lies almost wholly within the GMNF. Two ski centers"(Mountain Meadows and. Mountain Top) and additional public trails make this area very skiable. The many trails that criss-cross this region are of beginner to moderate difficulty. The ski routes in this section run from "end to end", with the exception of two trailess gaps (of apx. 4 and 3 miles), one between Mountain, Meadows and Mountain Top, the other north of Mountain Top.

Blueberry-Breadloaf Section, Route 73, to Lincoln Gap, 26.2 miles. The Blueberry-Breadloaf section lies on the western slope of the Green Mountains. The ski team was able to ski. over ski trails and unplowed forest service roads for most of the section's length." The average elevations are near to but beneath $2000^{\prime}$ and the route difficulty level is 
easy. The existing ski trail nétwork operated by Blueberry Hill and Breadloaf SkI Centers is well connected and extensive. Thisisection needs only a few short strategically. placed new trails to turn it into a complete and fine skiway. The location of many of these connector ski routes. coincides with federal government forest land, thus their. construction could likely be undertaken with a minimum" of problems.

Sugarbush-Map River Section, Lincoln Gap to Huntington Gap, 16.0 miles. This section passes through three ski touring centers (Sugarbush, Tucker Hill and Mad River Glen) which. are interconnected with some fine tracked ski trails. : The Sugarbush-Mad River Seotion is on the eastern side of the Main Range, where it collects and maintains snow longet into the season as compared to the champlain Valiey side. Trail elevations range from $1000^{\prime}$ to $2300, '$. Despite the range of elevations, the connecting ski trails are rated from beginner to moderate in difficulty, thus the region has a high skiability.

Camel's Hump Section, Huntington Gáp to Winooski River: 12.3 miles. This section's route traverses the west slope of the Malin Range at elevations above 1400!. It passes through both state forest and private land. Trail diffi-: culty, might be described as moderate, there, are several lengthy climbs, but the bulk of the route is composed of

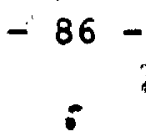




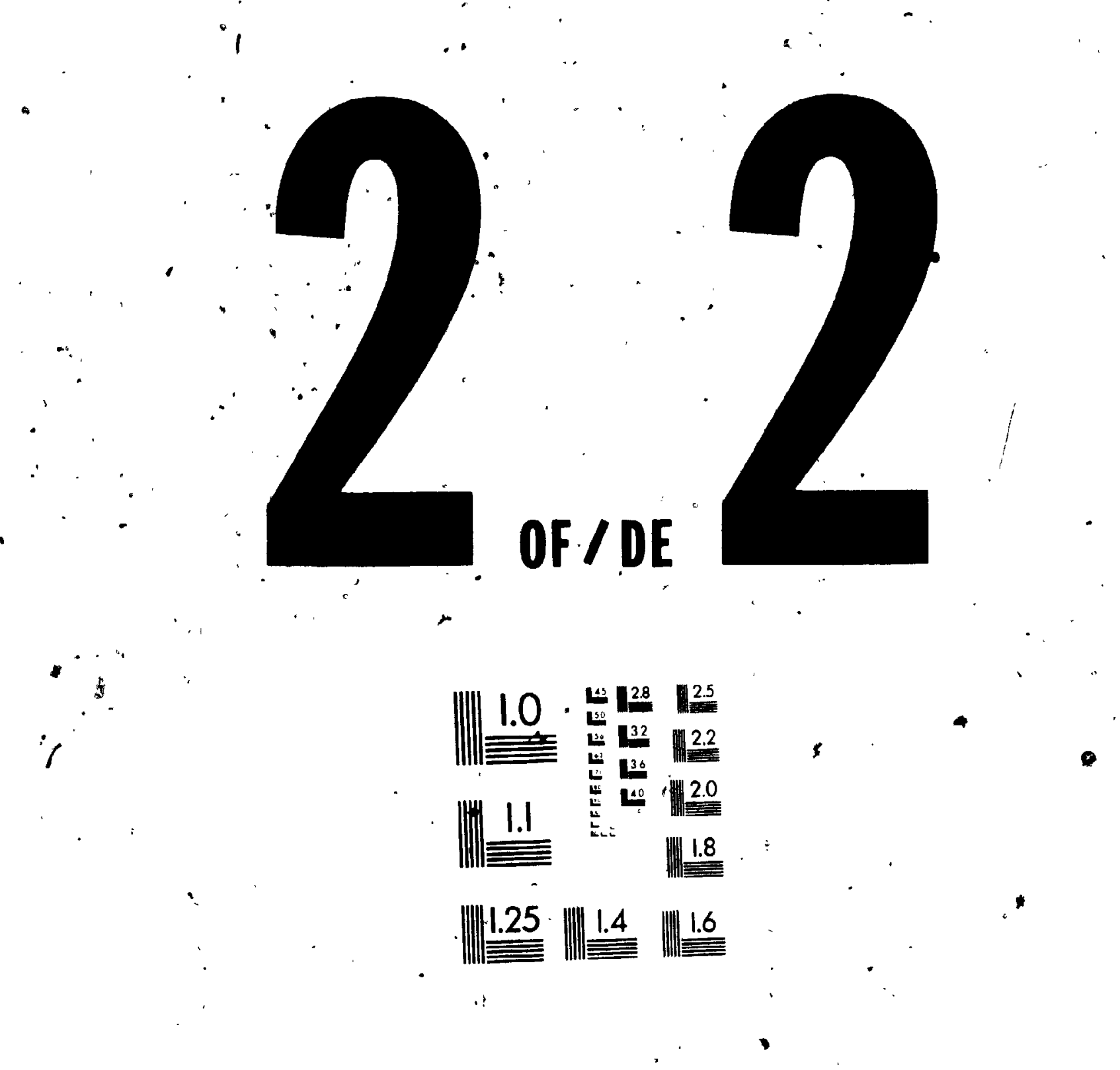


rolling hills. The Camel's Hump Nordic Ski Center has an extensive trail. network, which a'lready has almost half the distance of this section's route covered by their existing ski trails. The many unplowed roads running along the west slope are seen as likely connectors extending south to Huntington Gap. The scenif attributes of this route are superb, with many high mountains on the east and occasional - views of the Champlain Valley and the Adirondacks to the west.

Mount Mansfield Section, Winooski River to Smugglers Notch Village, 34.8 miles. The trail pathway through the Mount Mansfield section is completely intact. Situated between the poles of this section is Vermont's finest ski trail network, an area containing an estimated $300 \mathrm{~km}$ of trail, and 6 inter-connected ski centers. The proposed Catamount Trail follows routes that are, challenging, taking skiers through and beside many high mountains. The skier difflculty of the existing: "end to end".trail in this region is moderate to difficult.

Cinderella S'ection Smuggler's Notch Village to Montgomery Center, 26.l'miles. Before the March ski trip, several Northern Vermont skiers expressed doubts about the route-. way of this particular section and it was referred to as - the "cinderella leg". These doubts and criticisms were confirmed during the March test trip. This area had the 
lowest overall trail elevation of any section in the state, with many areas below '1000' and some below 500': The conditions encountered during the March' ski trip were poor. It. was discovered that the ski service infrastructure, on this western slope of the Main Range, is non-existent. There are no ski centers, ski trails or skier services. This is probably due to low elevations, which have a negative impact on snowcover. The significance of this is that this section does not fulfill the criteria established for creating sections of the catamount Trail and that alternate routes leading north should be considered.

Hazen's Notch Section, Montgomery Center to Jay, 16.7 miles. Montgomery Center is a, seenic village, wedged between shoulders of the Main Range and Cold Hollow Mountains. This trail section is 'argely above 1000' and ha's a reputation for considerable snowfall. The skiing infrastructure is developed with many services available in Jay and Montgomery Center. Hazen's Notch Ski Touring Center offers lodging and has trails leading toward Jay. The proposed routeway travels over a number of unplowed roads that also receive snowmobile use.

Maple Leaf Section, Jay to Bordar, 5.1 miles. The Maple Leaf'section has a pleasant rollilng landscape, with many farms and good views of the Jay Mountains. Currently there is no ski trail leading the short aistance to the border. 
The raw ingredients for a good ski trail exist, such, as a gentle terrain with dependable snow cover. The/ land is privately owned, but little posting in this region was observed by the author.

The Importance of the March test trip to the overall methodological process cannot be understated: The trip confirmed that the general pathway of the Catamount Trail offered a feasible route, especially since it could be skied in it's current state, as an "undeveloped" proposed continuous oki trail, composed of existing ski centers and trails. Observations relating to each designated ski section's ski characteristigs and qualities have enabled the author to identify two trail sections that offer less than acceptable skiing conditions. In the following final

- chapter, overall route feasibility will be reviewed/ assessed and recommendations will address the problem of the unacceptable sections and suggest that trail relocations be made that would provide better overall skiing conditions for users. 


\subsection{Thesis Review}

The primary purpose of this research has been twofold. First to identify the Vermont geographic, zones that provide the best physical environment and the most developed recreational infrastructure for cross-country skiing. The second goal has been to construct, test and evaluate, within the above-mentioned overlapping zones, a "Long Trail for cross-country skiers", that would connect varlous ski trails, ski trail networks and skier servịce centers into a ski route running the length of Vermont.

The research limitations of this study have been related not to a lack of information on Vermont cross-country sking, but rather to the geographically dispersed 'nature of this information. Because cross country skiing has only recently (within the last two decades) become a popular winter recreation in vermont, there have been no comprehensive state studies conducted to date regarding the sport. There is a conspicuous lack of information, gathered at any one location or data library. These limitations have been overcome with a research methodology that involved travel about vermont and the collection of dispersed pieces 'of information.

The research evidence collected indicates that there is an optimal environmental ski zone, generally located on eastern portions of the Green Mountain physiographic zone (Figure V). This environmental zone considerably ovepraps 
the optimal infrastructure zone (Figure $X$ ). These two zones and especially their area of overlap are seen as.the best location to propose the routing of a state length ski trail (Figure XI).

A mapping methodology was devised to specifically identify and chart the existing ski trails, ski trail networks and ski services within the optimal zones. This led to the creation of a ski trail proposal that was field tested in March 1983. The test trip confirmed the feisibility of the planned route. The test trip also identified sections of the catamount Trail that might be improved with locational adjustments, aimed at gaining better environmental and infrastructure conditions for the propsed pathway of the trail.

The popularity and demand for "end to end" trails in North America is seen in the development and use of hiking and skiing routes. The Maple Leaf Trail in the Laurentians, - the Brace and Rideà Trails are both in Ontario, the translength mountain range Appalachain and Pacific Crest Trails, - being in the United/states. Súch trails, including the catamount Trail proposal offer the outdoor recreationist opportunities ranging from short day or weekend trips to extended getaways, where the romance of the wilderness can be discovered and the pressures of modern society forgotten.

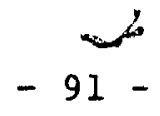


Patmore in Chapter II defines the "spatial impact of recreation as being largely confined to lines of movement linking nodes of intense activity". While recreationists employ a.diversity of appraoches in investigation of their field, there is no agreement on any integrated body of theory. Smith, (1982: 19) states that "The history of recreation geography is one of growing intellectual diversity with no convergence toward a set of ürified theories and methods". This thesis concerning the Catamount Trail has essentially had an applied, planning focus.

\subsection{Recommendations}

"Locational adjustments that would improve the quality of the overall trail route include 4 minor relocations when the trail has been moved eastward of the original route a short distance largely for safety reasons, and two major relocations. The Shrewsbury section in Central Vermont has been completely rejected (all 6.3 miles) and moved" eastward to higher elevations. The entire route between - the Mt. Mansfield Ski Touring Center in Stowe to the Jay village has been revised. In its place a route running to the east of the initial proposal passes through the town 
of Craftsbury. In all, $798\left(199^{\circ}\right.$ miles $)$ of the entire trail proposal exhibited 'a high skiability and thus escaped any need for route revision.

The following four trail relocations are minor in scope and involve moving the initial proposal pathway no more than several miles away from its original location. Based on the results of the March test trip it was deter mined that these minor adjustments might considerably improve the safety, climatic and snow cover conditions of the following trail segments.

1 and 2) Relocate to the east along the shoreline, the trails formerly running Qver the surface of Harriman and Somerset Reservoirs; in the southern and Mount snow-stratton Mountain Section's respectively. It was discovered that the level of the reservoirs and ice itself fluctuates Quring the winter, creating a zone of broken ice around the shoreline that at times may be somewhat wet and dangerous.

3) In the Mount Snow-Stratton Mountain Section, avoid the Haystack-Snow ridgeline trail since it is reputably exposed to high winds and difficult. Our team skied a fine alternative route which traversed the east slope of Mount Snow rather than the summit ridge.

4) The route between Mountain Top Ski Center and Blueberry Hill Ski Center should be moved eastward and to higher elevations to secure better snow and sking conditions. 
By using the Puss and Kill Brook Trail, (as was done), higher elevations were gdined and the actual distance between the two ski centers was shortened by about 4 miles. The two major trail relocations reqarding the Cinderella section and the Shrewsbury section are suggested because the initial proposal pathways exhibited a marginal. skiability due to poor environmental conditions and a. poorly developed. ski infrastructure. By moving both trail sections eastward and to higher elevations, 'more reliable snow and skiing conditions might be secured, but there would be little imprgvement in infrastructure conditions. The following major route revisions are seen as viable 'Catamount Trail segments but they háve not been' subjeçted to the rigorous research and testing of the initial proposed pathway. While research regarding environmental and infrastructure conditions can be conducted throughout the "year, testing of these revised suggestions can only occur during the winter season. Therefore these revisions should be 'further researched and fie"ld tested to determine their: feasibility.

Major Revisions:

1) The 6.3 mile long Shrewsbury Section should be dis'carded. It is known that' elevations of between $500^{\prime}$ to 1000' higher might be found 5 miles, to the east of this section. Without further pn site field research and 
discussions with local skiers it is impossible to determine the location of a better route in this central Vermont area. Therefore it is recommended that further research be conducted to determine the best possible location.

2) As related before, the route from the Mt. Mansfield Ski Touring Center to Jay lacks a high enough viability to seriously consider it for inclusion, into the Catamount Trail. A summary of the problems of this section (which is largely anchored by the cinderella section) has been made previously. Again as in most other cases, it is thought that the problems of inadequate snowpack can be somewhat alleviated by shifting the route to the east. John Brodhead of the Craftsbury Nordic Ski Center has sug- ' gested using the historic pathway of the old Bailey-Hazen Military Highway, completed in 1793. This highway, now largely unused, passes through Craftsbury and terminates in Hazen's Notch. From Hazen's Notch the trail could run down to Montgomery Center and loop back to the original route to the border via Jay. The route from stowe to Craftsbury is uncertain and would depend upon further field research.

\subsection{The Catamount Trail, A Final Overview}

The revised Catamount. Trail differs little from the initial plotted route. Thề half dozen minor and major 


\section{1}

revisions affected the location of only 218 of the route.

This final overview briefly considers the character of the entire route from Massachusetts to Canada. The. trail is discussed and reviewed using the "Macro criteria" for Planning the Route of a State Length Ski Trail", that was presented in section 2.3. The trail criteria are:

\section{1) safety}

2) length of ski season

3) trail use expectations

4) availability of skier services and facilities

5) trail difficulty

6) . land availability and accessibility

7) minimized trail development expense by maximal use of existing facilities and ski routes ."

8) avoidance of trail use conflicts

The following evaluations are based on interpretations made during the March test trip and reflect on the skiability of the proposed route of the catamount Trail.

The design and revisions of the Catamount Trail exhibit a high degree of safety consciousness. The trail plan recognizes and avoids placing the skier in hazardous environmental and infrastructure conditions. For example, steep terrain, potentially dangerous streams and reservoirs and snowmobile trails are generally avoided:

The major safety risk is the unpredictability of weather conditions. This peril is one that all skiers must understand, and be prepared for no matter where they are

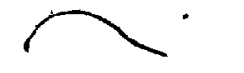


skiing. It is thus, a problem common to all extended lehgth ski trails and not specifically the Catamount Trails.

Because móst of the Catamount Trail is routed through areas with optimal environmental conditións, it/jhould under normal winter conditions have an extended ski season in most areas from later December to late March if not mid April. Snow depth, and dependability should be very good because of the route's high average elevation. There are only three short sections of trail below 1000'.

Expected trail use is variable. If the Catamount Trail were completely constructed from "end to end" "these areas leading to major ski centers would probably receive great use. The trail would probably attract a number of package ski trip tours of weekend and week duration. In addition to package tours many private overnight and longer tours would.occur. Since no other cross-country ski trail of this length exists in the Northeastern United States, the trail would probably attract more out-of-state use than in-state resident. use.

Avallability of skier services and facilities is a stxong point of the proposal. Figures XIX and XX indicate lodges in towns along the Catamount Trail. Twenty nine of the 37 towns the Catamount Trail passes through contain 226 lodges. Along the pathway of the trail itself are 22 ski centers. While these resources are not spread evenly, the March test trip demonstrated that their current avail- 


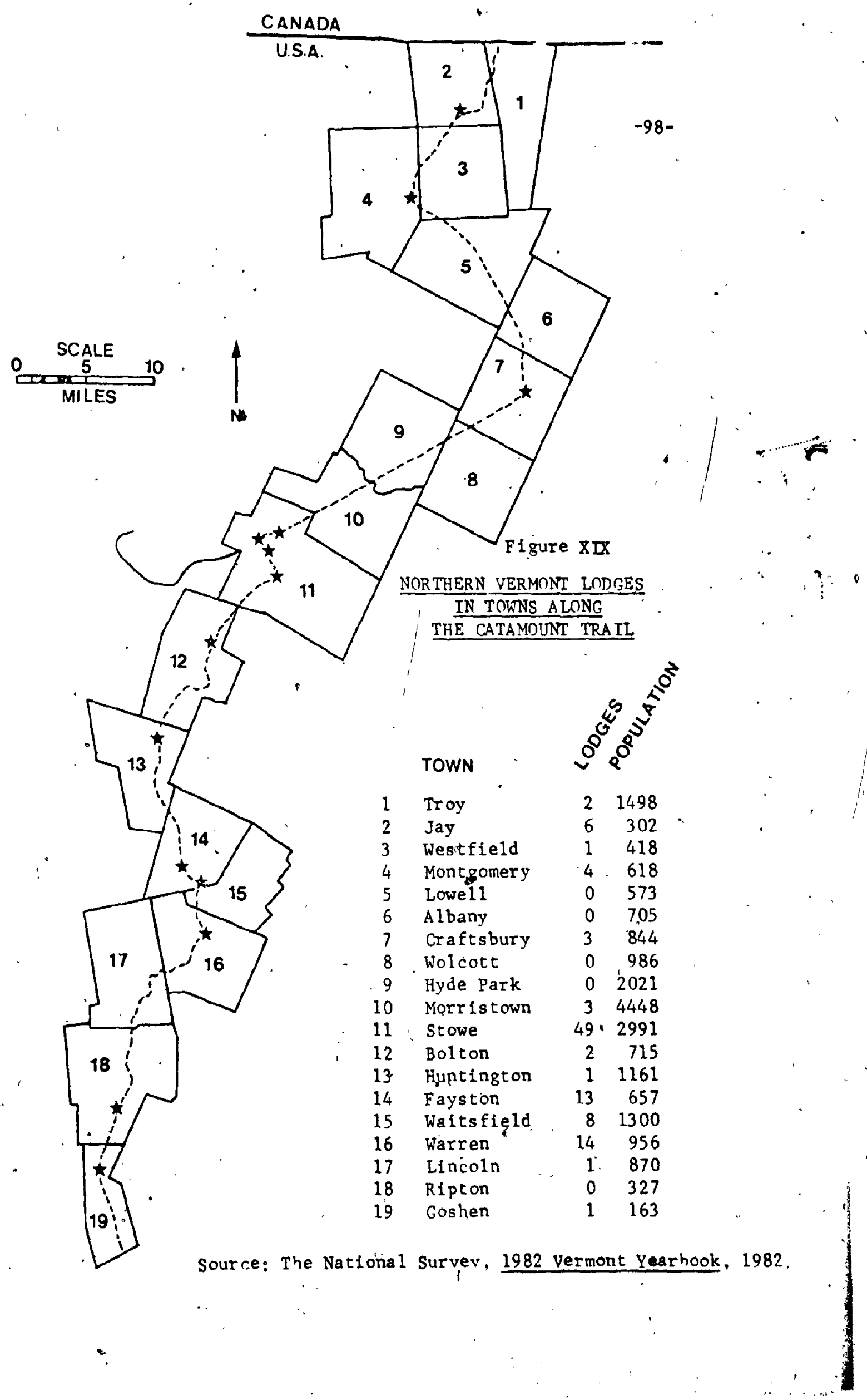




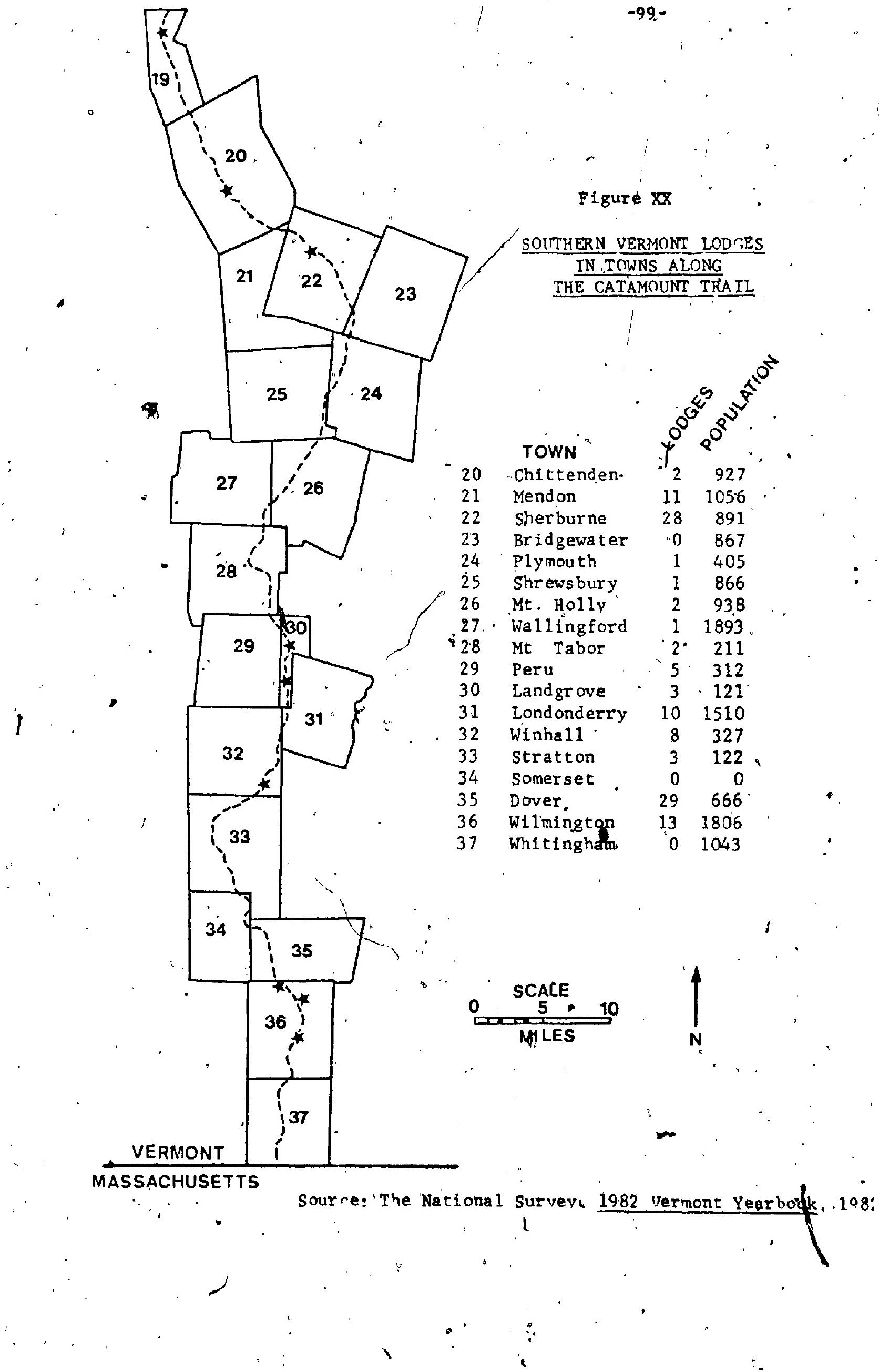


ability and location is adequate for arfanging a long tistance ski tour. The potential development of the catamount Trail might serve to attract additional services to. locate along the pathway of the trail.

The trail difficulty of the. Catamount trail is variable. The route sections for most of its length are easy to moderafe: The difficult sections are confined to the backcountry trails where a rapid elevation gain or loss is experienced. Much of the proposed path was existing ski trails and unplowed roads which are normally of easy to moderaté difficulty.

In areas whe ski trails are lacking, public land offers the greatest promise for new trail development necessary to link other services and ski trails. Figure $x$ indicates the ample distribution of public land in the Green Mountains. Noticeable concentrations are found in Southern and Central Vermont. The Catamount Trail passes througt large areas of 'State and National Forest Land which offers high potential for development of new ski trails.

The Catamount Trail proposal minimizes trail development expenses by maximizing use of existing facilities and ski routes. The current mil and location of ski trails, ski trall networks and ski services promotes further in1 terçonnection of resources. During the March test trip, the team skied almost three-quarters of the state's length - on existing ski routes, which whlè often not fully connected together, could be connected with strategic short 
trail links.

The pathway of the Catamount Trail has avoided use of snowmobile trails in order to prevent conflicts between skiers and snowmobilers. While coates (on p. 22) states that these two groups are incompatible, the author suggests that this is not always the case. The snowmobilers encountered during the March test trip were always friendly and courteous. Many skiers appreciate the packed trails left by snowmobiles. The trail proposal does incorporate many unplowed roads, which are wide enough to allow safe shared use by both user groups. In situations where safety is not a concern in the use of public resources, such as unplowed roads, a dialogue between both user groups might alleviate the possibility of conflict.

Extensive research and testing have generated recommendations for several, improvements in the proposed Catamount Trail route. The final determination regarding the proposals overall. feasibility, is that the ski pathway displays great potential for becoming a popular winter recreation traill for cross-country skiers. 
Allaben, Stanton. "Public Lands Provide Unlimited Potential for Ski Trails". Nordic Skiing, October, 1976, $14-16$.

- Vermont Ski Trail Guide: South Central Region. Londonderry, Vt.: Stanton Allaben Productions, 1982. - Vermont Ski Trail Guide: Central Region. Londonderry, Vt.: Stanton Allaben Productions, 1983.

Bushey, Steve, ed.. Vermont Cross-Country Ski Atlás. Burlington, vt.: Northern Cartographic, 1983.

Caldwell, John. The New Cross-Country Ski Book'. '4th ed.. Brattleboro, Vt.: Stephen Greene Press; 1976..

Clawson, M. and J.K. Knetsch. Economics of Outdoor Recreation. Baltimore: John Hopkińs Press, 1971.

Coates, William. "User Conflicts on Recreation Trails". Ottawa: National Capital Commision, 1981. (Address presented at the International Conference on Winter Recreation.)

Ford, Sally and Daniel. 25 șki Tours in the Green Mountains. Somersworth, N.H.: New Hampshire Publishing Company, 1978.

Guide Book to the Long Trail. 20th ed.. Rutland, Vermont: Green Mountain Club, Inc., 1971.

Heller, Mark, ed.: The Skier's Encyclopedia. New York: Paddington Press, Ltd., 1979.

Henneberger, John, ed.. 1982 Vermont Year Book. . Chester, vt.: The National survey, 1982.

Honeyman, Susan June. A History of Skiing in Montreal and the Laurentians. University, 1974 .

B.A. thesis, Kingston, Queen's

Lavery, Patrick, ed.. Recreational Geography. Vancouver: Douglas David \& Charles Limited, 1971 .

Lindsay, John. The Quality and Use of Vermont's Hiking Trail System, Burlington. Vt.: School of Natural Resources, University of Vermont, 1983.

$$
-102-
$$


Lousteau, Rod. Guide to the Ski Touring Centers of New England. Chester, Ct.: The Globe Pequot Press, 1980.

Ludlum, David. The Country Journal New England weather Book. Boston: Houghton Mifflin Company, 1976.

Marsh, John and Wall, Geoffrey. Recreational Land Use Perspectives on Its Evolution in Canada. Ottawa: Carleton University Press, 1982.

Meeks, Harold A.. The Geographic Regions of Vermont A Study in Maps. Hanover, N.H.: Dartmouth Geography Publications, 1975.

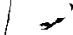

Ontario Ski Council Inc.: Cross-Country Ski Trail and Facility Design Manual. Willowdale, Ont.: Ontario Ski Coluncil, C. 1980 .

- Pigrarn, John. Outdoor Recreation and Resource Management. London: Croom Helm, Ltd., 1983.

Simmons, I.G.. Rural. Recreation in the Industrial World. London: Edward Arnold Ltd., 1975.

Ski Touring Council. Ski Touring Guide. 16th. ed.. Troy, Vt.: 1979.

Smith, Stephen. "Reflections on the Development of Geographic Research in Recreation: Hey. Buddy, Can You S'paradigm?". Ontario Geography, No. 19, 1982, 5-28.

Squier, Elizabeth. Guide to the Recommended Country Inns of New England. 8th.e ed. Chester, Conn:: The Globe Pequot Press, 1981.

Statistics Canada. Participation in Downhill and CrossCountry Skiing. Ottawa: Education, Science and Culture Division, October, 1976.

United States Geodetic Survèy topographic maps. Vermont collection with scales of $1: 62,500$ and $1: 24,0,00$.

Tapley, Lance. Ski Touring in New England and New York. 2nd. ed.. Brattleboro: Stephen Greene Press, 1978.

Tourism and Recreation Studies B̈ranch. Skiing at Ontario Resorts Winter $1971 / 72$. Toronto: Ontario Ministry of Industry and Tourism, 1973.

Vermont Agency of Environmental Conservation. Vermont State Comprehensive Outdoor Recreation Plan. Montpelier: 1978. 
0

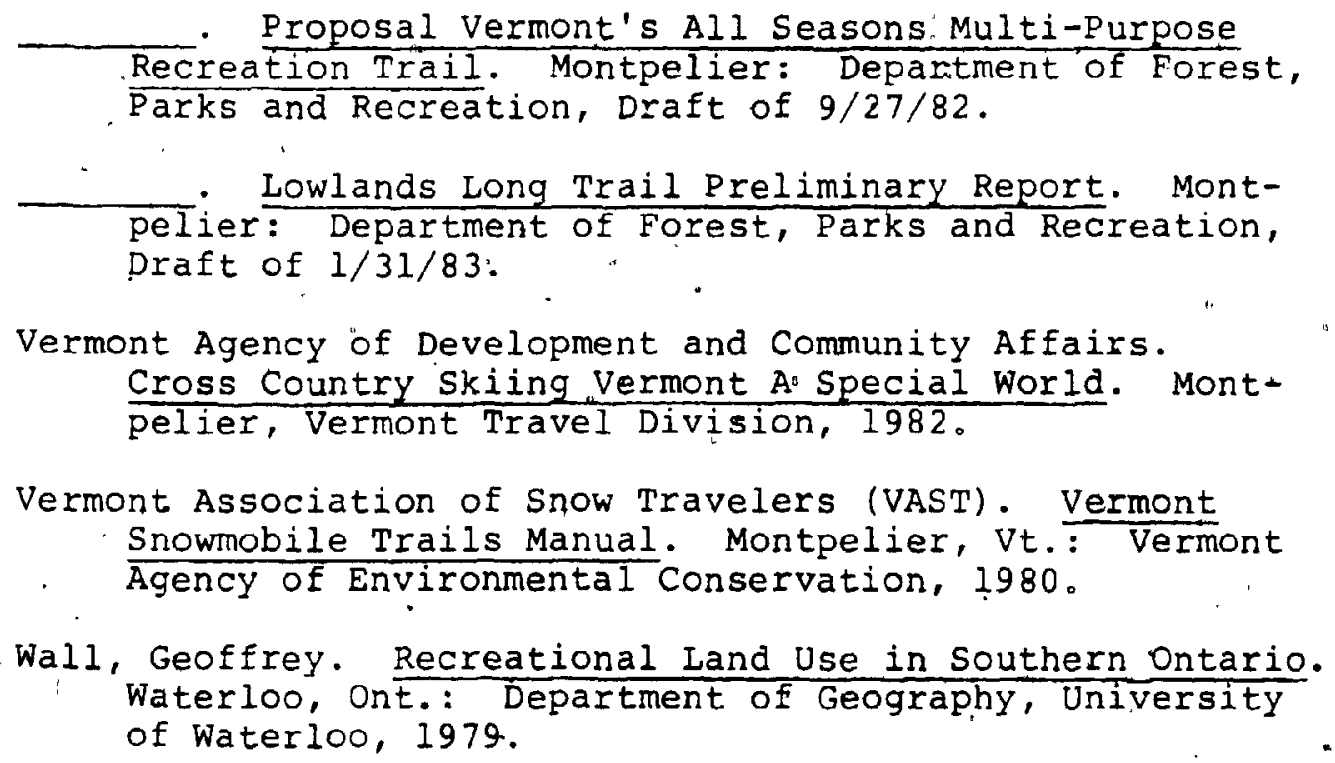

$-104-$ 

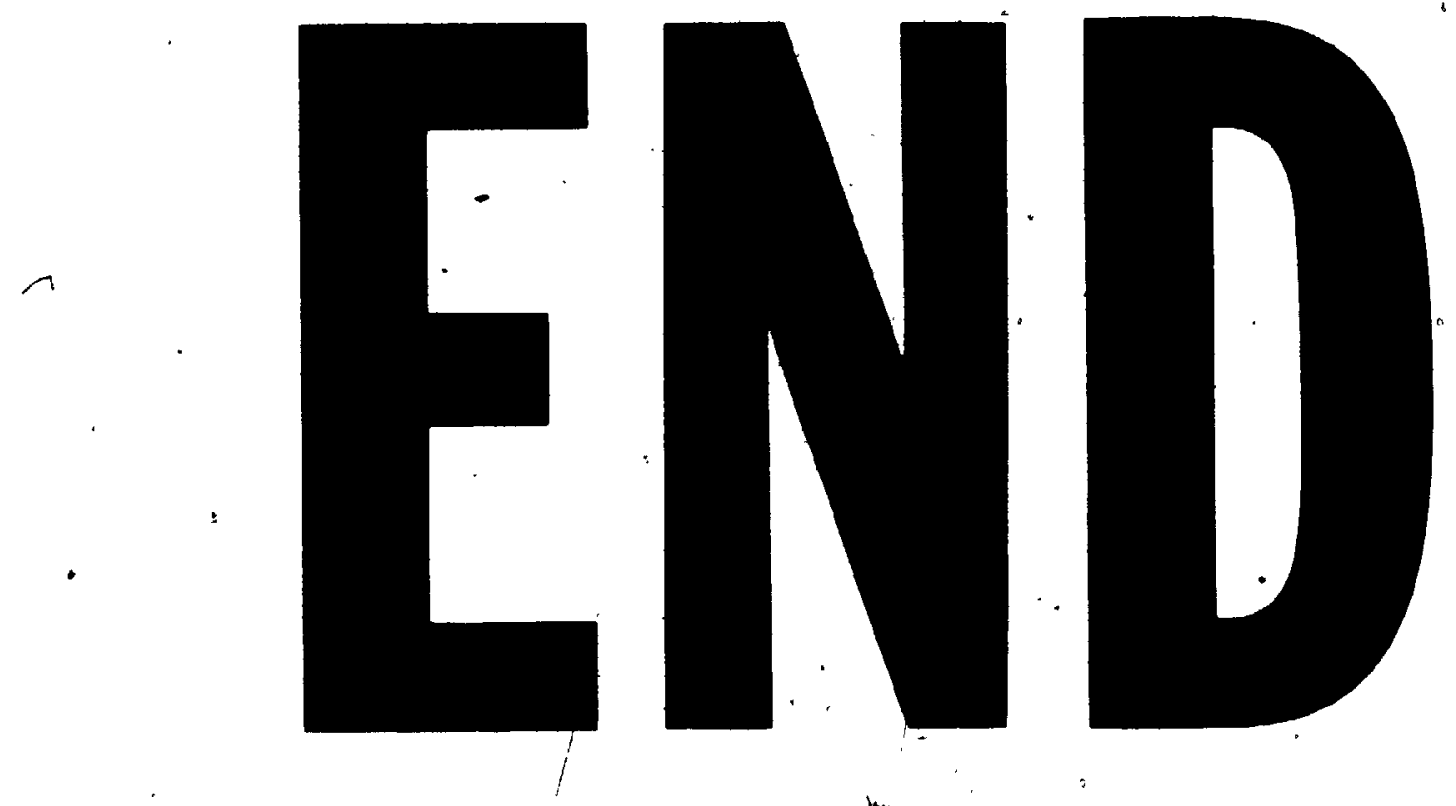

$\checkmark$
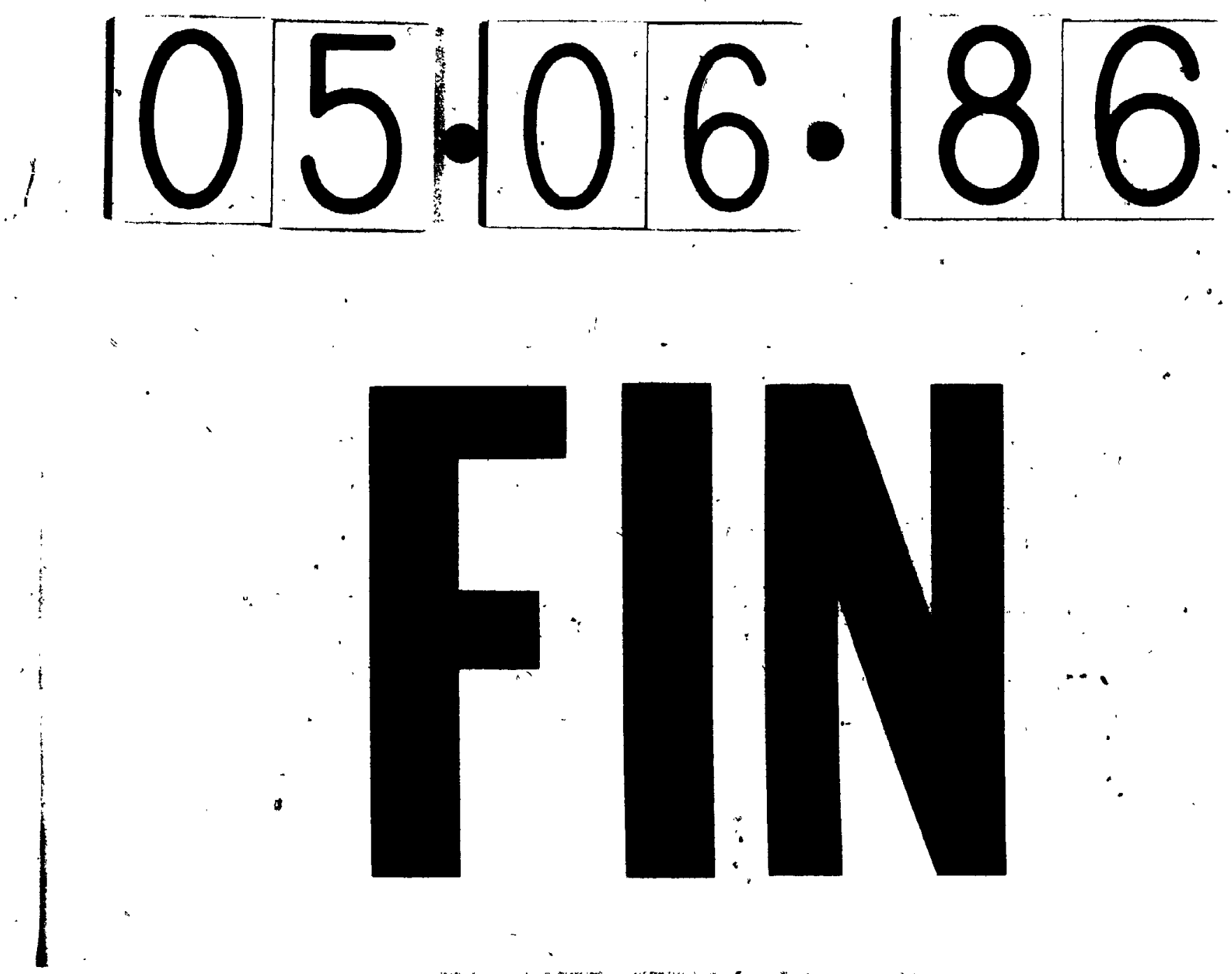

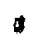

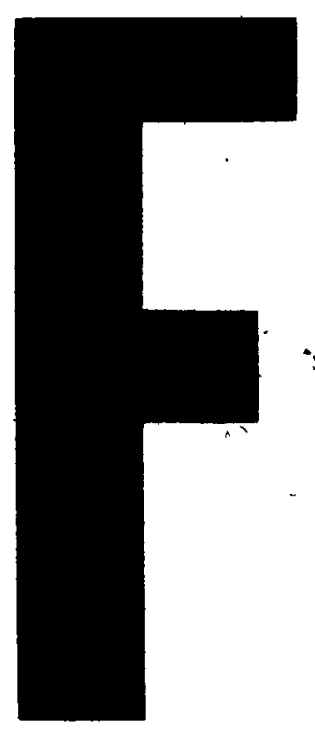

